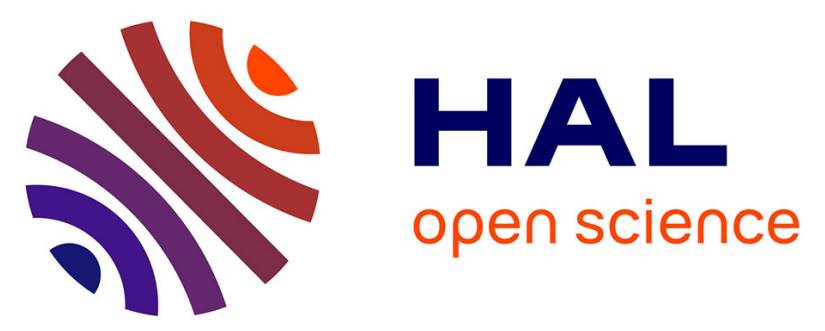

\title{
ВЛИЯНИЕ ТЕРМИЧЕСКОЙ ОБРАБОТКИ ИСХОДНОГО РАСПЛАВА НА СТРУКТУРУ И СВОЙСТВА КРИСТАЛЛИЧЕСКИХ СЛИТКОВ ИЛИ ОТЛИВОК
}

\author{
P.S. Popel, V.E. Sidorov, I.G. Brodova, M. Calvo-Dahlborg, U. Dahlborg
}

\section{To cite this version:}

P.S. Popel, V.E. Sidorov, I.G. Brodova, M. Calvo-Dahlborg, U. Dahlborg. ВЛИЯНИЕ ТЕРМИЧЕСКОЙ ОБРАБОТКИ ИСХОДНОГО РАСПЛАВА НА СТРУКТУРУ И СВОЙСТВА КРИСТАЛЛИЧЕСКИХ СЛИТКОВ ИЛИ ОТЛИВОК. Расплавы, 2020, 1, pp.3-36. 〈10.31857/S0235010620010065〉. 〈hal-02609476〉

\section{HAL Id: hal-02609476 \\ https://hal.science/hal-02609476}

Submitted on 10 Nov 2020

HAL is a multi-disciplinary open access archive for the deposit and dissemination of scientific research documents, whether they are published or not. The documents may come from teaching and research institutions in France or abroad, or from public or private research centers.
L'archive ouverte pluridisciplinaire HAL, est destinée au dépôt et à la diffusion de documents scientifiques de niveau recherche, publiés ou non, émanant des établissements d'enseignement et de recherche français ou étrangers, des laboratoires publics ou privés. 


\title{
ВЛИЯНИЕ ТЕРМИЧЕСКОЙ ОБРАБОТКИ ИСХОДНОГО РАСПЛАВА НА СТРУКТУРУ И СВОЙСТВА КРИСТАЛЛИЧЕСКИХ СЛИТКОВ ИЛИ ОТЛИВОК
}

\author{
С 2020 г. П. С. Попель ${ }^{a, ~ *, ~ В . ~ Е . ~ С и д о р о в ~}{ }^{a, b}$, И. Г. Бродова ${ }^{c}$, \\ М. Кальво-Дальборг ${ }^{d}$, У. Дальборг ${ }^{d}$ \\ ${ }^{{ }_{1}}$ ральский государственный педагогический уншберситет, Екамеринбург, Россия

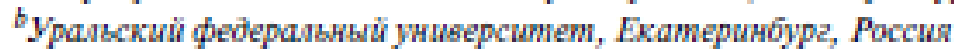 \\ ${ }^{\prime}$ Институт физики металов им. М.Н. Михеева УрО РАН, Екатеринбург, Россив

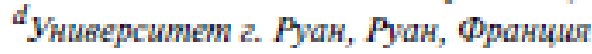 \\ "e-mail: pspopel@mail.ru
}

Поступила в редакцию 21.06.2019 г.

После доработки $12.08 .2019 \mathrm{r}$

Принята к публикации 14.09 .2019 r.

\begin{abstract}
Расемотрены современные предстанления о строснии жидких металлов и сплавов. Показано, что в жидких металлических растворах могут существовать несколько типов микронеоднородности и микрогетерогенности. Их етруктурное состояние изменлетея в результате вариации состана и предыстории, температуры и давления или влияния различных внешних воздействиЙ. При последующем охлахдснии с подходящей скоростью эти изменения могут сохраньтъея нплоть до ликвидуса и влиять на етрукгуру и свойстна затвердевшего сплава. Главное внимание обращено на влияние температуры нагрева жицкого металла. Для сплавов на основе алюминия показана возможность разработки оптимальных термических режимов ныплавки с иепользованием результатов исследования структуры и свойств распланов. Показано, что такая оптимизированная термическая обработка расплавов явллестея эффективным способом повышения качества спланов.
\end{abstract}

Ключевые спова: расплавы, микронеоднородность, микрогетерогенность, структурные пренращения, перегрев, алюминиеные сплавы

DOI: $10.31857 / \mathrm{S} 0235010620010065$

\section{ВВЕДЕНИЕ}

Подавляющее большинство технологических процессов производства металлических сплавов включают перевод шихтовых материалов в расплавленное состояние и последующее затвердевание системы с различными, иногда очень высокими, скоростями охлаждения. В попытках улучшить структуру и служебные своиства слитков, отливок и деформированных полуфабрикатов технологи обращали болышое внимание на поиск оптимальных условии затвердевания. И только первая стадия этого процесса - исходныи расплав - традиционно оставался за пределами интересов металлургов. В большинстве случаев попьтки повлиять на систему на этом этапе заключались в дополнительном легировании с целью оптимизации ее состава или в рафинировании для удаления вредных примесеи.

Однако в последние 50-60 лет в научнои периодике накопилось большое количество данных, которые свидетельствовали о том, что металлические расплавы являются весьма сложными динамическими системами. Они могут существовать в различных структурных состояниях и переходить из одного такого состояния в другое под деиствием различных внешних воздеиствии. Была установлена и роль структурного со- 
стояния исходного расплава в формировании структуры и своиств слитков, получаемых из этого расплава и в дальнейем структуры и своиств деформированных полуфабрикатов. Применительно к сталям, чугунам и некоторым никелевым сплавам эти факты были систематизированы в монографии Б. Баума с сотрудниками [1], изданнои в 1984 г. и в коллективнои монографии [2]. И.Г. Бродова, П.С. Попель и Г.И. Эскин в книге [3] обобщили свои данные о влиянии обработки жидкого металла при производстве алюминиевых сплавов. Краткии обзор влияния температурнои обработки расплавов на свояства аморфных материалов был сделан в [4].

В этои статье мы попытаемся рассмотреть влияние термическои обработки исходных расплавов на структуру и своиства кристаллических металлических сплавов. Будет показано, что существует несколько типов микронеоднородности и микрогетерогенности жидких металлических растворов. Их структура зависит от состава, температуры и предыстории. Используя вариации температуры и давления и другие физические воздеиствия, эту структуру можно модифицировать. При подходящеи скорости охлаждения удается сохранить изменения строения расплава вплоть до ликвидуса и сохранить эффект этих воздеиствии в структуре и своиствах закристаллизовавшегося сплава. Будет сформулирована идея о возможнои эффективности оптимизированнои термообработки расплава как простеишего внешнего воздеиствия на жидкометаллическую систему. Далее мы суммируем результаты применения этого воздеиствия, при производстве алюминиевых сплавов в традиционных металлургических процессах, которые характеризуются умеренными скоростями охлаждения (порядка $1-10^{3 \circ} \mathrm{C} / \mathrm{c}$ ).

\section{МИКРОНЕОДНОРОДНОСТЬ И МИКРОГЕТЕРОГЕННОСТЬ ЖИДКИХ СПЛАВОВ}

\section{Ближсний порядок и структурнше превраицения в жсидкостях}

В расплавленных металлах и сплавах сильное взаимодеиствие частиц существенно ограничивает их относительные расположения; результирующая корреляция носит название локального, или ближнего порядка. Природа этого упорядочения и размеры кластеров с сильно коррелированными положениями частиц зависят от состава материала, температуры и давления. Атомное упорядочение в мальх кластерах простых веществ с плотнои упаковкои атомов часто интерпретируется как фрагменты гексагональнои плотноИ упаковки, или кубическои гранецентрированнои решетки, или икосаэдров [5]. Этот локальныи порядок может характеризоваться геометрическими параметрами, инвариантными по отношению к поворотам (например, координационными расстояниями и числами, характеристическими углами в кривых рассеяния). Для того, чтобы учесть ограничения, налагаемые на относительные положения частиц локальным порядком, систему описывают в терминах параметров локального (ближнего) порядка.

Металлические расплавы относятся к системам с сильным взаимодеиствием частиц. Поэтому есть основания ожидать, что ближнее упорядочение в них будет близко к кристаллическому. Мы предполагаем, что для таких систем локальныи порядок сохраняется благодаря сильным взаимодеиствиям на близких расстояниях и несущественно изменяется даже после того, как глобальное упорядочение разрушается при плавлении. Последнее явление описывается как результат прорастания топологических дефектов с такои их плотностью, которая достаточно мала для идентификации локальнои структуры $[6,7]$. В терминах локального порядка при этом допускаются флуктуаци ориентащий осеи локальнои симметрии с потерей их корреляции на некотором конечном расстоянии. В случае присутствия только одного вида ближнего упорядочения это приводит к ориентационнои модели плавления $[8,9]$. 
Взаимодеиствием атомов в однокомпонентном веществе может быть обусловлен дополнительныи тип локального порядка. В твердом теле конкуренция между различными типами ближнего порядка приводит к полиморфным фазовым переходам. Следуя этои идее, была сформулирована схематическая модель вещества с гамильтонианом, записанным в терминах локальных кристаллических состоянии кластеров и ориентации в размещении этих кластеров, и исследованы фазовые переходы в этои модели [10]. Если дополнительныи тип локального порядка может быть получен в результате полиморфного превращения вещества, эта модель предсказывает существование полиморфных структурных переходов в расплавах. Л. Сон и Г. Русаков [11] применили теорию локальных состоянии, предложенную в [6], к чистым жидким металлам с различными видами локального упорядочения и показали существование температур и давлении, при которых вероятности этих упорядочении кардинально изменяются. Исследуя поведение свободнои энергии вблизи этих точек, они классифицировали эти превращения в жидком металле как фазовые переходы первого порядка.

Железо является наиболее распространенным металлом, которыи демонстрирует полиморфные фазовые переходы вблизи точки плавления и для которого можно предположить наличие сильного локального упорядочения. Следовательно, естественно допустить, что для железа и систем на его осноре могут иметь место полиморфные фазовые переходы в расплавленном состоянии.

И деиствительно, было зафиксировано множество аномалии на зависимостях своиство-температура жидкого железа в температурном интернале $1640-1680^{\circ} \mathrm{C}$, которые можно интерпретировать как косвенные свидетельства преобразовании локального порядка [12]. Некоторые авторы связывали эти эффекты с резкими изменениями содержания примесеи. Однако в ходе измерении магнитнои восприимчивости $\chi$ жидкого железа В. Сидоровым [13] было показано, что чем меныше концентрация примесей в образце, тем более отчетливо проявляется аномалия в виде скачка на кривои $\chi(T)$. Следовательно, эта аномалия связана не с примесями, а с изменением локального порядка жидкого железа. Эксперименты по дифракции ренттеновского излучения [14] показали, что ниже температуры аномалии $T_{\text {an }}$ характерные межатомные расстояния и координационные числа жидкого железа соответствуют $\delta$-структуре исходного кристалла, а при $T>T_{\text {an }}$ она становится $\gamma$-подобнои.

В кристаллическом двухкомпонентном сплаве с ограниченнои смешиваемостью компонентов обычно имеют дело с как минимум двумя типами локального порядка, каждыи из которых соответствует фазе с доминированием одного из компонентов. Было показано, что для двух типов локального порядка, обусловленных двухкомпонентностью системы, в модели [10] имеют место два различных фазовых перехода: ориентационныи переход порядок-беспорядок, идентифицируемыи как плавление, и фазовыи переход между фазами с различнои концентрацией компонентов; этот последнии переход имеет место как в кристаллическом, так и в расплавленном состояниях. Фазовая диаграмма этои модели, по-видимому, совпадает с хорошо известными диаграммами с эвтектическим и монотектическим равновесиями.

Используя теорию локальных состоянии бинарных растворов [10], Л. Сон и Г. Русаков предположили существование ГЦК-подобного, ОЦК-подобного и цементито-подобного локальных упорядочении в расплавах $\mathrm{Fe}-\mathrm{C}$ и рассчитали все известные линии фазовои диаграммы этои системы по всего нескольким ее известным точкам (рис. 1). Наиболее интересныи факт: эта модель предсказывает возможность продолжения линии фазового перехода $\delta-\gamma$ в область жидкого состояния, где эта линия исчезает в критическои точке. На рис. 1 в виде кружков нанесены положения аномалии магнитнои восприимчивости, зафиксированные В. Сидоровым и др. в [13]. Они очень близки к расчетнои кривои равновесия, экстраполированнои в область жидкого состовния. 


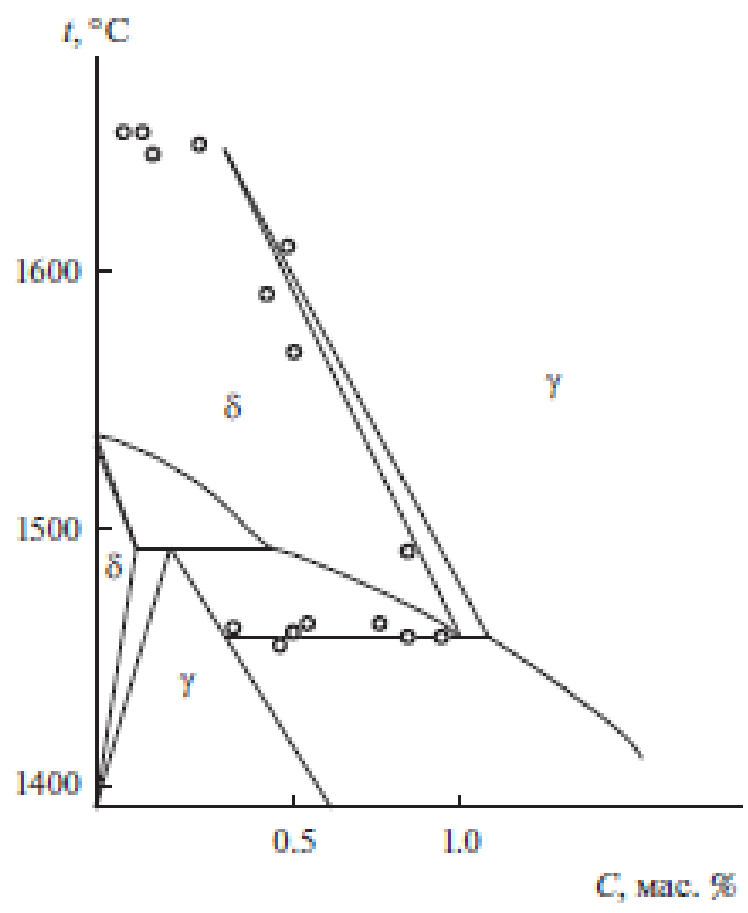

Рщс. 1. Модифициронанная фазовая диаграмма системы Fе-C [10]. Положения аномалии магнитнои носприимчиности, определенные в [13], отмечени кружками.

Следовательно, структура бинарных и многокомпонентных жидких сплавов может рассматриваться как смесь кластеров на основе различньг атомов, погруженных в жидкии преобладающии компонент. Например, структура расплавов $\mathrm{Fe}-\mathrm{B}$ обычно представляется как кластеры на основе бора, окруженные матрицей жидкого железа. Следовательно, жидкие металлические растворы являются неоднородными в микроскопическом масштабе, т.е. микронеоднородньми.

Кластеры, обогащенные различными компонентами, не имеют четкой межфазнои гранищы с окружающим расплавом: их локальныи состав и локальная структура постепенно изменяются с ростом расстояния от центрального атома и совпадают с составом и структурой матрицы на расстоянии 1-2 нм.

Другои тип возможнои микронеоднородности жидких сплавов, склонных к аморфизащии, рассматривался в [15]. Авторы стартовали от наблюдения, что зависимость вязкости этих расплавов от температуры существенно отличаются от закона Аррениуса. Это можно интерпретировать как свидетельство роста структурных единиц вязкого течения при понижении температуры. Согласно их гипотезе, этот эффект связан с формированием крупномасштабных цепочек или сетей атомов металлоида, связанных ковалентными связями. Л. Сон и В. Сидоров [15] разработали оригинальныи вариант статистическои теории ассоциированных растворов, применимыи на любом масштабе полимеризации. Ее применение к бинарнои системе $\mathrm{A}_{x} \mathrm{~B}_{1-x}$, где $\mathrm{A}$ - атомы могут быть связаны ковалентным образом, показали нерегулярное критическое поведение, характерное для неметаллических стеклообразующих систем. Этот переход был связан с преобразованием от глобулярнои структуры ковалентных связей к разветвленнои.

Таким образом, мы приходим к заключению, что существует несколько видов микронеоднородности жидких металлов и сплавов. Можно изменять масштаб и типы объ- 
единения атомов путем изменения температуры расплава или различными внешними воздеиствиями на него.

\section{Метастабильная микрогетерогенность}

Наряду с вышеупомянутыми кластерами, цепочками и сетями, в бинарных и многокомпонентных жидких металлических растворах могуг существовать более крупные области, обогащенные одним из компонентов, размером порядка 10-100 нм. Эти области отделены от окружающего расплава четкои межфазнои гранищеи [16]. Поэтому система в целом является гетерогеннои на нанометрическом уровне, или микрогетероzенной. Первые убедительные свидетельства этого факта были обнаружены в седиментационных экспериментах [17]. Автор отметил необычное обогащение тяжелым компонентом нижнеи части эвтектических расплавов под деиствием естественнои гравитации или их периферическои части при вращении в центрифуге. При исследовании температурных зависимостей своиств и структуры ближнего порядка таких расплавов мы поняли [18], что эти микрогетерогенные состояния являются не термодинамически устоичивыми, а метастабшльнми или неравновесньми (согласно классификации Гиббса, мы рассматриваем метастабильные состояния как равновесные, но обладающие ограниченнои устоичивостью по отношению к внешним возбуждениям и имеющие ограниченное время жизни). Главнои причинои их появления являются не особенности межатомного взаимодеиствия, а начальная гетерогенность расплава, возникшая из-за его предыстории (например, из-за плавления гетерогенного слитка с эвтектикои и первичными кристаллами, нагрева расслоенного расплава выше купола несмешиваемости, смешения компонентов при температуре, незначительно превышающеи ликвидус или купол расслаивания и т.Д.). После этого система релаксирует к термодинамически устоичивому состоянию истинного раствора, но этот процесс, вопервых, может протекать в аномально медленном кинетическом режиме, а во-вторых, может завершиться установлением метастабильного равновесия между дисперсными частищами, обогащенными одним из компонентов, и окружающим расплавом, обогащенным другим. Характерное время жизни этого метастабильного состояния при малом $\left(10-50^{\circ} \mathrm{C}\right)$ перегреве над ликвидусом имеет порядок $1-10$ ч.

При нагреве микрогетерогенного расплава выше определеннои для каждого состава температуры он необратимо переходит в состояние истинного раствора. Это явление подтверждается ветвлением температурных зависимостеи своиств, измеренных при нагреве и последующем охлаждении образцов (гистерезис своиств). Следовательно, абсцисса точки ветвления может быть классифицирована как температура гомогенизации $T_{\mathrm{h}}$.

В качестве примера на рис. 2 показана зависимость поверхностного натяжения расплавов $\mathrm{Ni}-\mathrm{B}$ от температуры [19]. Мы полагаем, что ниже точки ветвления $T_{\mathrm{h}}$ расплав, образовавшиися после плавления исходного слитка, является микрогетерогенным. Вблизи $T_{\mathrm{h}}$ он необратимо переходит в состояние истинного раствора. Нанося точки $T_{\mathrm{h}}$ для различных составов на фазовую диаграмму системы Ni-B, мы получаем куполообразную кривую, внутри которои существует метастабильная микрогетерогенность расплавов (рис. 3 ).

Довольно убедительными результатами в пользу метастабильнои микрогетерогенности жидких сплавов были получены и в ходе исследования температурнои зависимости магнитнои восприимчивости $\chi$ расплава Au-Со эвтектического состава [20]. Эта система представляет особыи интерес, поскольку ее точка эвтектики лежит несколько ниже точки Кюри $T_{\mathrm{C}}$ твердых растворов, богатых кобальтом. Следовательно, если дисперсные фрагменты исходных эвтектических фаз после плавления деиствительно сохраняются в этоИ системе, можно было ожидать существенных магнитных 


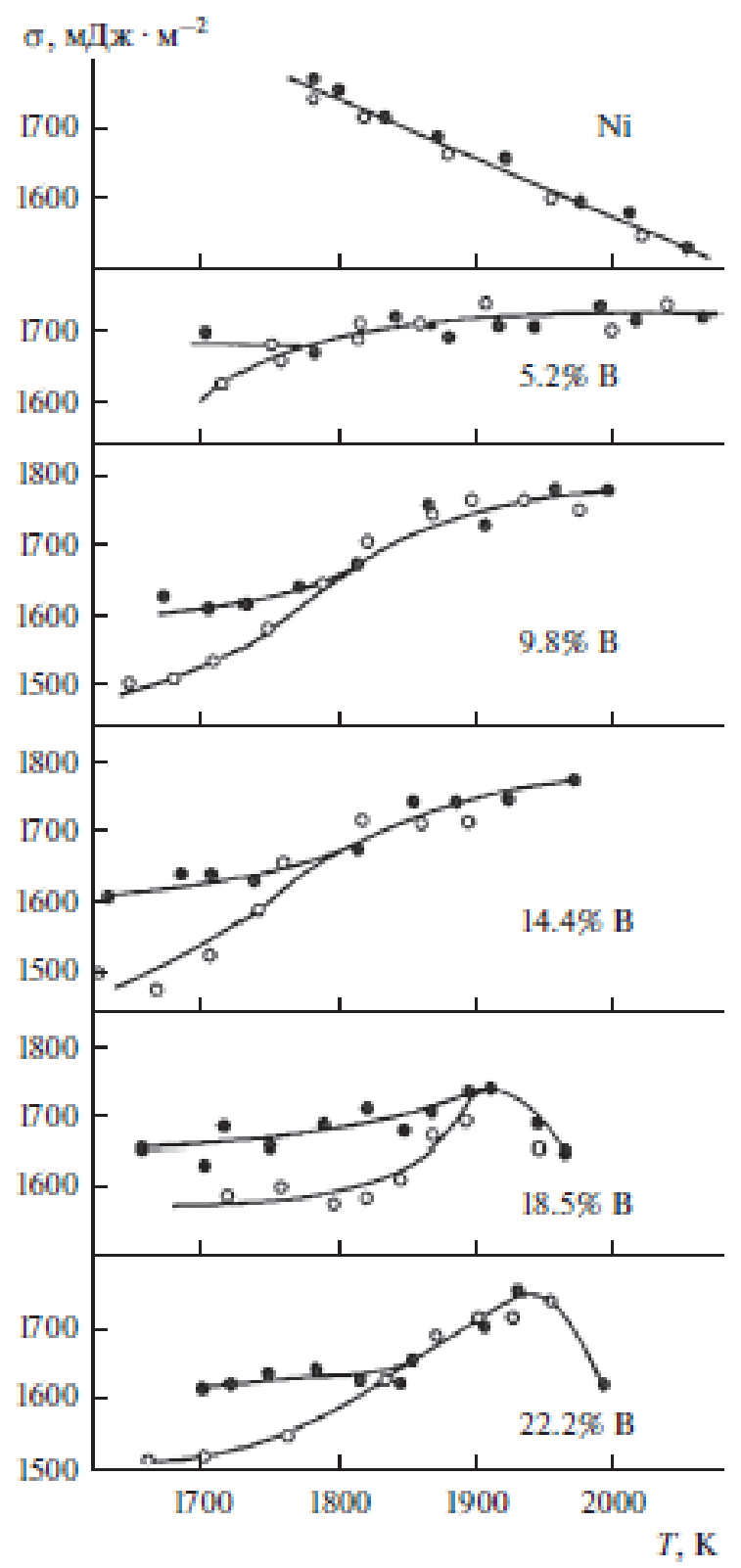

Рис. 2. Температурные занисимости поверхностного наттжения расплавов Ni-B, полученные при нагрене после планления (•) и при последуюцем охлаждении (о).

эффектов, связанных с исчезновением ферромагнетизма в дисперсных частицах на основе кобальта.

Результаты экспериментов, представленные на рис. 4, подтверждают это предположение: на кривых $\chi(T)$, полученных при нагреве образца после плавления, ясно видна отчетливая аномалия вблизи температуры Кюри сплавов, богатых кобальтом. Если расплав не был перегрет существенно выше $T_{\mathrm{C}}$, зависимость $\chi(T)$, полученная при его охлаждении, воспроизводит кривую нагрева вместе с отмеченнои аномалиеи. Однако если наследственная микрогетерогенность была разрушена в результате нагрева до 


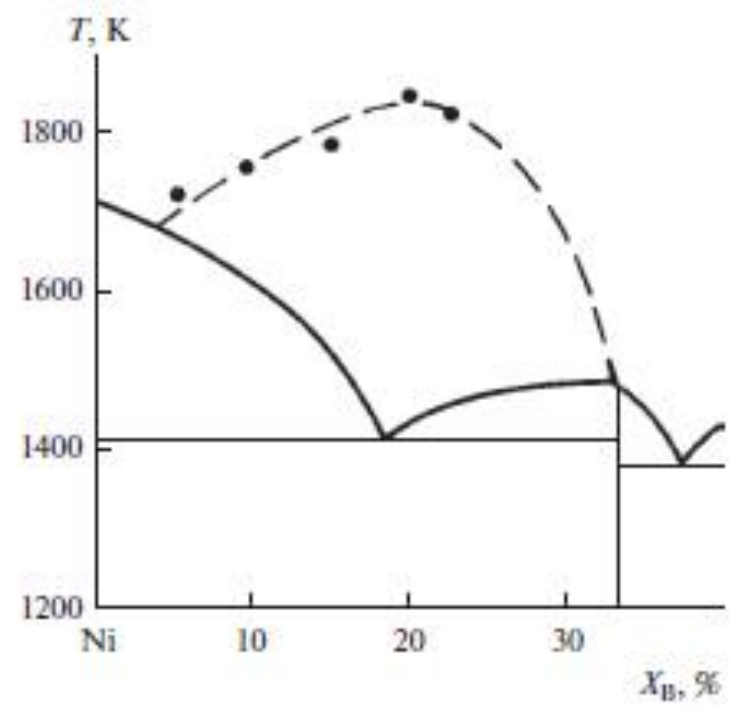

Pмс. 3. Фазовая диаграмма системи Ni-B. Пунктирная линия над ликвидусом ограничивает область метастабильноя микрогетерогенности распланон.
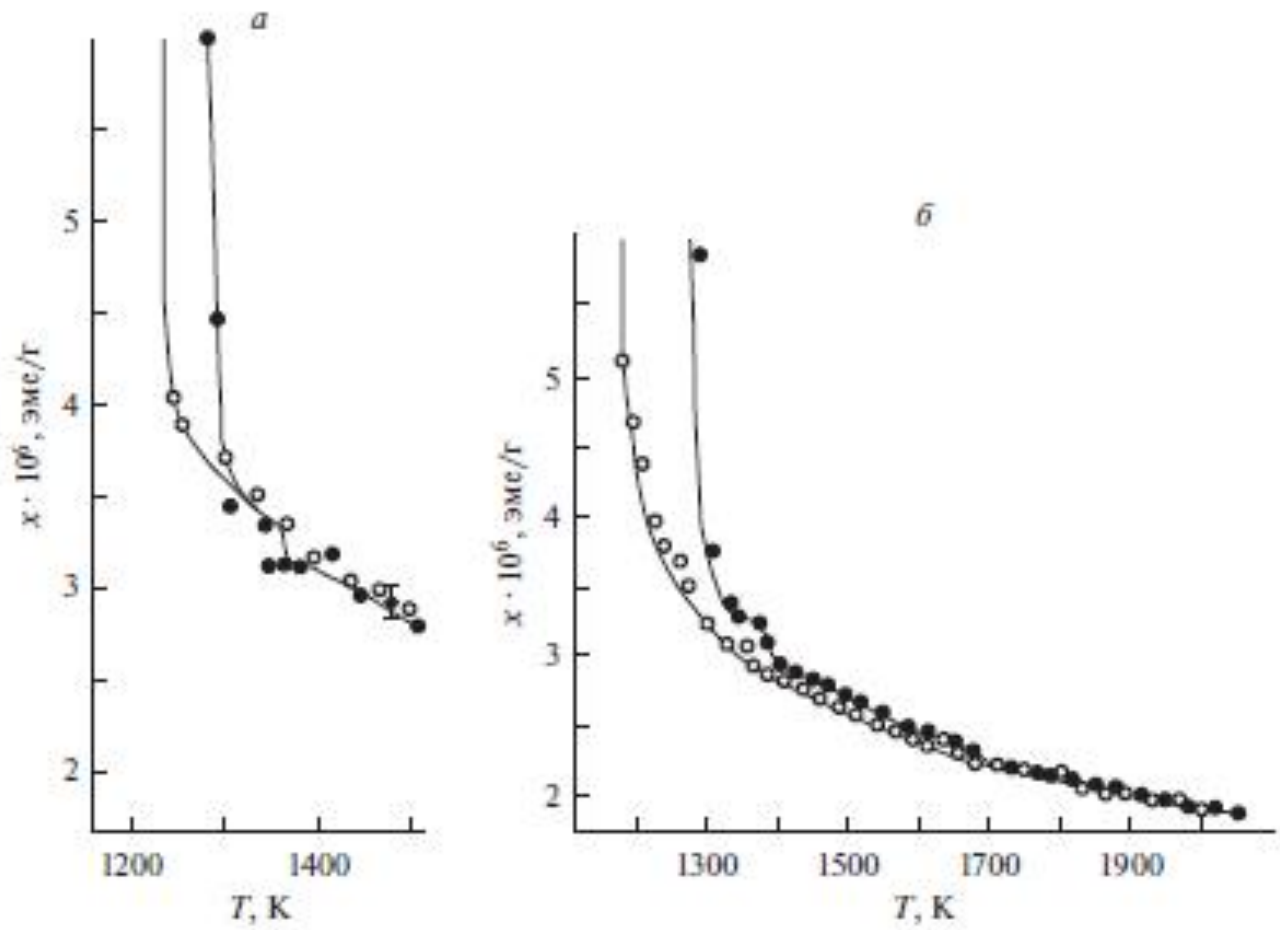

Pмс. 4. Температурные зависимости магнитнои восприимчивости сплава $\mathrm{Au}-27$ at. \& Со, полученние при нагреве до 1240 ( а) и до $1790^{\circ} \mathrm{C}(6)(\bullet)$ и при поспедующем охлаждении (о) [21]. Напрмхеность магнитного none $H=5.7+10^{5} \mathrm{~A} \cdot \mathrm{M}^{-1}$. 
$1800^{\circ} \mathrm{C}$ и система перешла в состояние гомогенного раствора, температурная зависимость восприимчивости ниже $1400^{\circ} \mathrm{C}$ отклоняется от кривои нагрева и не имеет особенностей вплоть до эвтектической температуры.

Еще один важныи эффект ярко проявился в этих экспериментах и впоследствии был подтвержден при изучении других систем: после необратимого перехода расплава в гомогенное состояние образец затвердевал при значительно болышем переохлаждении, чем не гомогенизированныи образец. Известно, что уровень переохлаждения на фронте кристаллизащии является главным фактором, определяющим рост кристалла и, следовательно, структуру и своиства формирующегося слитка. Следовательно, гомогенизирующии перегрев расплава должен оказывать существенное влияние на качество литого металла.

Мы провели также исследование дифракции электронов в сплаве $\mathrm{Sn}-\mathrm{Pb}$ эвтектического состава [21]. Было показано, что после плавления образца максимумы радиальнои функции распределения атомов, полученнои в результате Фурье-преобразования его структурного фактора, совпадают с характерными межатомными расстояниями жидких свинца и олова. Это согласуется с представлением о микрогетерогенности pacплава. При температуре $480^{\circ} \mathrm{C}$ максимумы и структурного фактора, и функции распределения существенно изменяют свою форму и свое положение, что свидетельствует об исчезновении микрообластеи, обогащенных различными компонентами, и образовании гомогенного раствора. Когда температура расплава понижается после его нагрева выше $480^{\circ} \mathrm{C}$, дифракщионные кривые остаются неизменными, т.е. сохраняется микрогомогенное состояние. Позднее необратимые изменения структурного фактора этого расплава после его нагрева до $650^{\circ} \mathrm{C}$ были зафиксированы в ходе его исследования методом дифракции неитронов [21].

Интересно отметить, что образцы, нагретые в жидком состоянии до температур ниже $430^{\circ} \mathrm{C}$, затвердевали при последующем охлаждении в эвтектическую структуру с четко выраженным триплетом дифракщионных колец, соответствующих кристаллическим свинцу и олову. Однако если расплав нагревали выше $480-580^{\circ} \mathrm{C}$ и таким образом переводили его в состояние истинного раствора, рефлексы свинца в дифракционнои картине затвердевших образцов исчезали, а линии олова существенно смешались, что свидетельствовало о формировании аномально пересыщенного твердого раствора свинца в олове. Это финальное состояние неизменно восстанавливалось после ряда последовательньх циклов плавления-кристаллизации данного твердого раствора. Оно также сохранялось и после длительнои выдержки образцов при комнатнои температуре. Таким образом, в этом исследовании было получено первое экспериментальное свидетельство того, что переход микрогетерогенного расплава в состояние гомогенного раствора (этот процесс мы называем гом огенизацией расплава) сопровождается радикальными изменениями структуры затвердевших образцов.

Первое прямое доказательство метастабильнои микрогетерогенности эвтектического расплава $\mathrm{Sn}-\mathrm{Pb}$ было получено при его исследовании методом малоуглового рассеяния неитронов (МУРН) [21]. Как сообщлось выше, согласно денситометрическим данным, его плотность при нагреве обнаруживает аномальное поредение, не существующее при последующем охлаждении (рис. $5 a$ ). Для того, чтобы понять, не связано ли это явление с какими-то структурными изменениями, были проведены измерения дифракции неитронов при $250^{\circ} \mathrm{C}$ до и после того, как расплав был нагрет до $650^{\circ} \mathrm{C}$. Как видно на рис. 56, имеется отчетливое различие между этими измерениями, свидетельствующее не только о том, что в результате этои термообработки расплава происходит изменение его структуры, но и о том, что после нее расплав становится более однородным.

Дальнеишие исследования малоуглового рассеяния нейтронов (МУРН) подтвердили эту интерпретащию и дали возможность получить более детальную информацию о микроструктуре расплава. В частности, функции распределения частиц по размерам, 

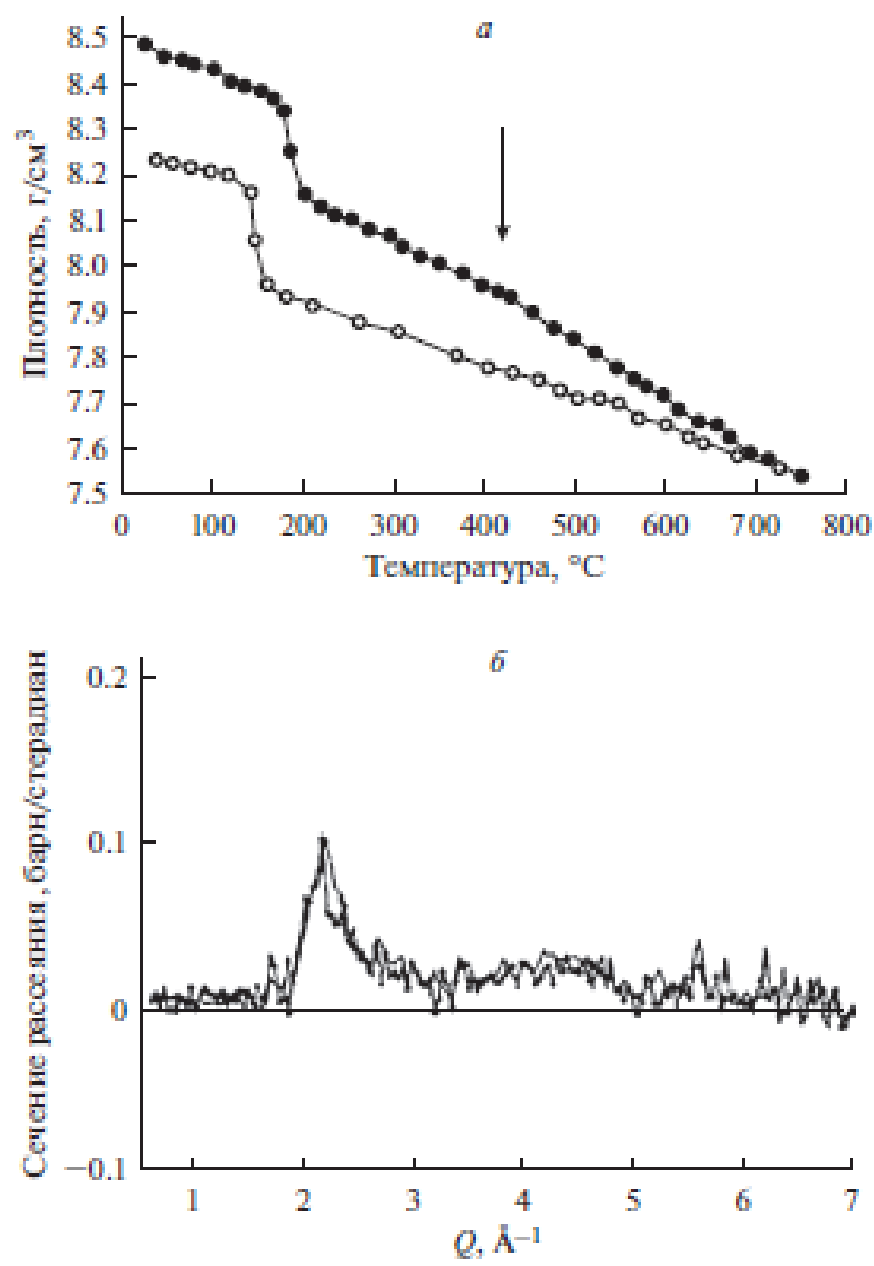

Pмс. 5. (а) Плотность эвтектического расплава Pb-Sn как функция темперагури при нагреве (•) и последующем охлахдении (о). (6) Разница между статитескими структурними факторами, измеренными при $250^{\circ} \mathrm{C}$ до и после натрева расплана до $650^{\circ} \mathrm{C}$ (вато из [21]).

полученные из этих данных и приведенные на рис. 6, четко свидетельствует о том, что расплав содержал области с атомнои конщентрациеи, отличнои от окружающего расплава. Эти зоны неоднородности постепенно растворяются при нагреве до $650^{\circ} \mathrm{C}$ и частично рекомбинируют при последующем охлаждении. На рис. 6 можно видеть, что области двух различных размерных грушп присутствуют в различных количествах при всех исследованных температурах: одна со средним размером около $1.8 \pm 0.5$ нм и еще одна, средние размеры которых немного изменяются с температурои в интервале от 30 до 90 нм.

Иногда необратимыи переход расплавов в состояние истинного раствора проходит в несколько этапов. Например, на рис. 7 показана температурная зависимость плотности расплава $\mathrm{Ni}-22.5$ ат. \% В [22]. Авторы установили, что после плавления образца и его изотермическои выдержки в течение 5-20 ч с ростом его температуры значения плотности уменьшаются. Далее, при двух или трех "критических" температурах $T_{\mathrm{C}}$ вновь появляется нестабильность плотности, и она изменяется со временем в тече- 

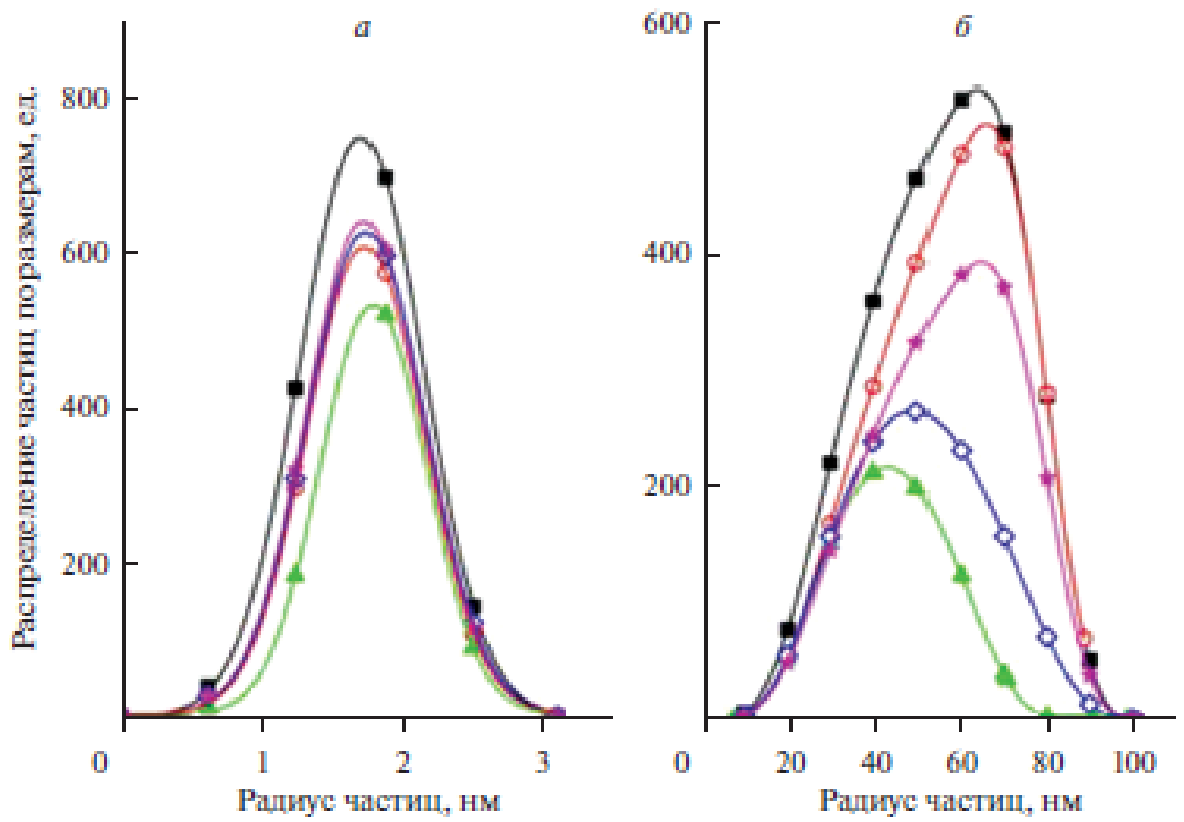

Рмс. 6. Функция распределения тастиц по размерам дли расплапленного эвтектического сплава $\mathrm{Pb}-\mathrm{Sn}$ при

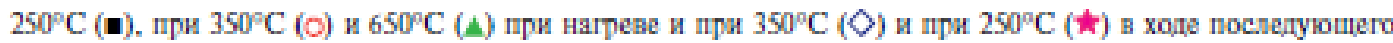
охлаждения: (а) для малых атомных группировок и (6) для болыпих зтомных группировок (взято из [22]).

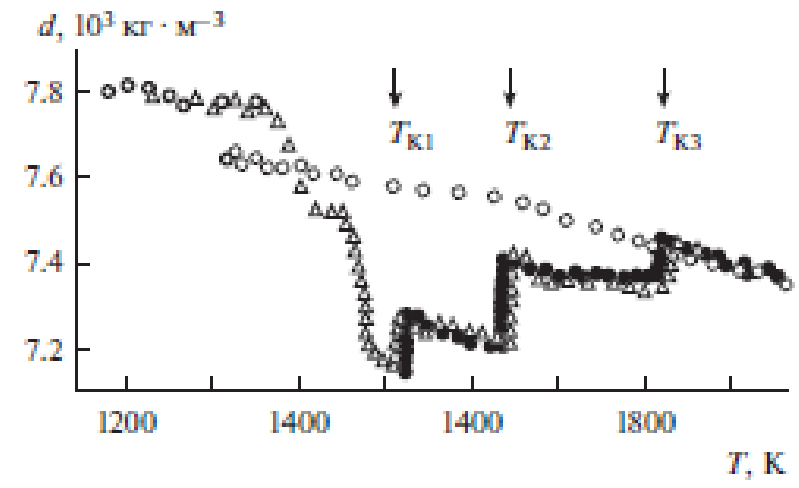

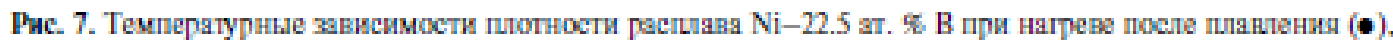
последуюцем охлаждении (о) и при вторичном натреве после кристалтизаџии обрезца и его повторного плавления $(\Delta)[22]$.

ние 5-10 ч. После установления новоһ "равновесноһ" величины плотности, в ходе последу ющего нагрева снова наблюдается устоичивая линеиная зависимость $d(T)$, однако при следующеи "критическои" температуре ситуация повторяется. И только после завершения релаксащии, при последнеи $T_{\mathrm{C}}$, зависимость $d(T)$ становится линеинои при последующем нагреве, охлаждении и термоциклировании без кристаллизации. Если же мы закристаллизуем образец и снова его расплавим, на кривои $d(T)$ будут наблюдаться те же самые особенности, что и при первом нагреве (рис. 7). Мы 


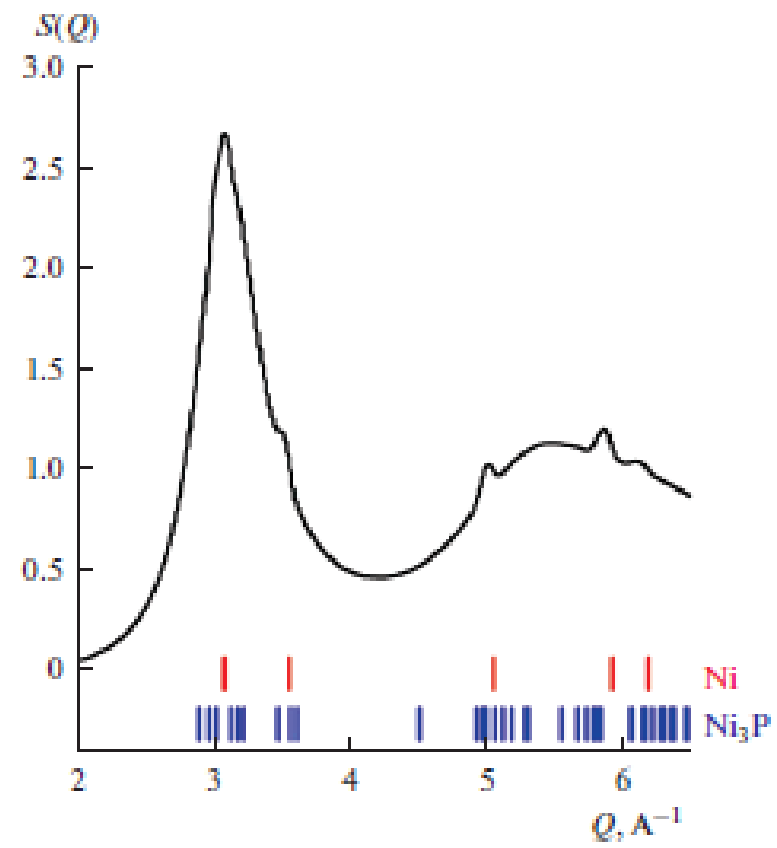

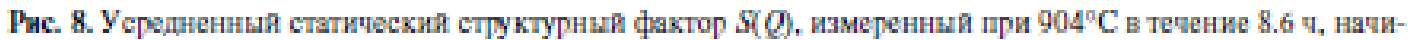
ная перез 3.1 п после натала температурного цикла. Вертикальнше линии в нижнеи пасти рисунка показынают положения наиболее интенсивнцх дифракционных пиков $\mathrm{Ni}_{3} \mathrm{P}$, нзятые из кристаллографитеских данHWX JCPDS.

полагаем, что этот расплав становится микрогомогенным после нескольких структурных превращения его микрогетерогенноЯ структуры, которые и обусловливают нестабильность плотности при "критических" температурах. Убедительное подтверждение этих идей было недавно получено при использовании метода дифракции неитронов для изучения временных зависимостеи структуры расплава эвтектического состава $\mathrm{Ni}_{81} \mathrm{P}_{19}$ [23]. Этот образец выдерживался приблизительно при $900^{\circ} \mathrm{C}$, т.е. гораздо выше точки плавления (около $850^{\circ} \mathrm{C}$ ), в течение более трех часов, прежде чем начинали запись данных. Усредненныи по времени статическии структурныи фактор S(Q), полученныи в течение последующих 9 ч измерении при температуре $904^{\circ} \mathrm{C}$, показан на рис. 8. Эта кривая $S(Q)$ имеет форму, характерную для расплавленнои системы, но на ней можно заметить некоторые неболышие пики, наложенные на плавную кривую. Можно заключить, что, несмотря на длительную изотермическую выдержку до начала измерения, в расплаве присутствуют хорошо определяемые кристаллические включения. Положения пиков, наблюдаемых на измереннои кривои, соответствуют первым пяти дифракционным пикам кристалиического никеля; никаких признаков кристаллического $\mathrm{Ni}_{3} \mathrm{P}$ не наблюдалось.

Более детально были проанализированы изменения интенсивности дифракционных пиков $\mathrm{Ni}(220)$ и (311), имеющих место при первых измерениях при $904^{\circ} \mathrm{C}$ и последуюших при $952^{\circ} \mathrm{C}$ (рис. 9). Измеренные интенсивности аппроксимированы экспоненциальнои зависимостью. Было обнаружено, что времена структурнои релаксации $T$ в обоих случаях составляли около четырех часов для пика $(220)$ и несколько меныше для пика (311). Аппроксимированные кривые удовлетворительно описывают приведенные экспериментальные данные, но необходимо подчеркнуть, что эти данные, конечно, могут быть описаны и другими подобными аналитическими выражени- 

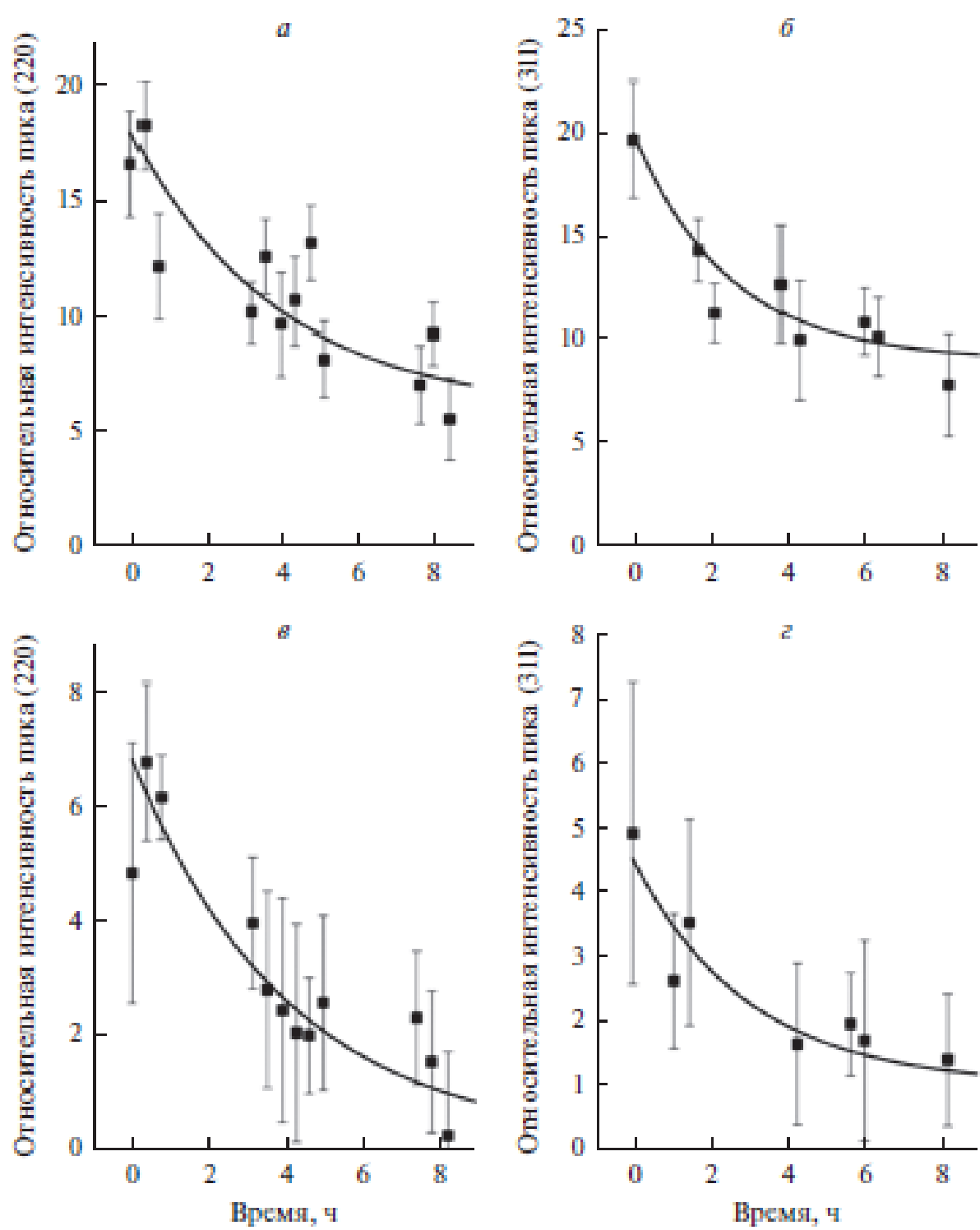

Рмс. 9. Изменения со временем дифрахщионных пиков Ni (220) и (311): пик (220) при температуре 904 (а) и $952^{\circ} \mathrm{C}$ (е); пик (311) при 904 (6) и $952^{\circ} \mathrm{C}$ (z). Кривые полурены как результат экспоненциальнои аппроксимации экспериментальных данных.

ями. Однако это не отменяет того факта, что, очевидно, достаточно крупные для обнаружения в дифракщионных экспериментах частицы никеля (т.е. болышие, чем порядка 10 нм) существуют в эвтектическом распларе $\mathrm{Ni}-\mathrm{P}$ в течение десятков часов в интервале температур ширинои в $100^{\circ} \mathrm{C}$ выше эвтектическои температуры.

Специфическии тип микрогетерогенности металлических расплавов связан с газовоИ подсистемои. Изрестно, что жидкие сплавы содержат значительные количества газовых компонентов. Например, содержание водорода в расплавленных алюминиевых сплавах существенно превышает его максимальную растворимость. Это означает, что значительная часть водорода существует в виде пузырьков или гидридов. В ходе термодинамического анализа [24] мы показали, что малые (порядка 10 нм) газовые пу- 
зырьки, в зависимости от пересыщения, температуры $T$ и давления $p$, могут существовать в устоичивом или метастабильном равновесии с окружающим расплавом. Следовательно, пересыщенные металлические расплавы должны рассматриваться как нанодисперсные пены. Изменяя $T$ и $p$, можно изменять дисперсность пены или переводить ее в состояние истинного газового раствора.

Термическая обработка расплава как перспективный метод произеодтва сплавов

Итак, можно рассматривать следующие типы микронеоднородности и микрогетерогенности жидких металлических растворов:

- Микроскопическая неоднородность, которая обусловлена различными видами локального упорядочения и может быть изменена в результате изменения обьемнои доли кластеров или полиморфных изменении внутри кластеров;

- Среднемасштабная фрактальная неоднородность, которая обусловлена существованием двух или более типов межатомных взаимодеиствии и может быть изменена вследствие эволюции металлоидных цепочек: их удлинением, объединением в сети, коагуляцией в глобулы и т.д.;

- Наномасштабная метастабильная микрогетерогенность, которая обусловлена предысторией расплава и может быть изменена в результате преобразований обьемнои доли, размеров и состава дисперсных частиц или нано-пуузырьков.

Учитывая, что различные виды микронеоднородности и микрогетерогенности обычно сосуществуют, приходится заключить, что металлические расплавы представляют собои очень сложные системы. Их структуру можно изменять в результате изменении температуры, или давления, или влияния на нее различными внешними воздеиствиями. При последующем охлаждении с подходящеи скоростью эти изменения могут быть сохранены вплоть до температуры ликвидус и оказывать влияние на структуру и своиства затвердевшего (кристаллического, нанокристаллического или аморфного) сплава. Данные о структурных перестроиках в металлических расплавах, представленные выше, позволяют обозначить наиболее перспективные способы внешних воздеиствий на жидкие металлы и сплавы с целью повышения качества литых, деформированных и быстро закаленных изделии из них.

Одним из них является обработка жидких сплавов мощными ультразвуковыми колебаниями, которая сопровождается развитием акустическои кавитации и акустических потоков в обьеме металла. В результате появления кавитационных пузырьков, их фрагментирования в более мелкие и последующего захлопывания может быть достигнута эффективная гомогенизация расплава [3]. Конечно, такая обработка расплава требует довольно сложного оборудования и может быть осуществлена только для не слишком высокотемпературных систем.

Температурная обработка жидких металлов и сплавов (перегрев над ликвидусом до некоторои температуры, изотермическая выдержка при этои температуре в течение определенного времени и последующее затвердевание с подходящей скоростью охлаждения) более проста, но не менее эффективна. Не предпринималось попыток применить ее к чистым жидким металлам с целью инициации фазовых переходов, описанных в работах Л. Сона и др., и сохранения высокотемпературнои структуры при достаточно быстром охлаждении до кристаллизации. Однако она представляется довольно перспективным направлением улучшения кристаллическои структуры металлов, склонных к таким переходам.

Наиболее радикальным способом представляется гомогенизирующая термическая обработка первоначально микрогетерогенных расплавов. Их перегрев над ликвидусом до температуры, превышающеи точку необратимого перехода системы в состояние истинного раствора, позволяет существенным образом повлиять на условия формирования фаз в процессе затвердевания и на своиства затвердевших сплавов. Повыше- 
ние максимальнои температуры выплавки без выхода за пределы области метастабильнои микрогетерогенности может привести к менее значительным, но также полезным эффектам. Изменения дисперсности и состава фаз микрогетерогенного расплава, достигаемые в процессе такои обработки, при достаточно высоких скоростях охлаждения могут сохраниться до начала кристаллизащии, обеспечивая модифицирование литого металла.

Во многих случаях значительныи перегрев жидкого сплава не может быть осуществлен в промышленных условиях вследствие недостаточнои мощности плавильного оборудования, низкои стоикости огнеупоров и других технологических и экономических ограничении. Вследствие этого возникает проблема снижения температуры гомогенизации расплава до приемлемых величин. Эта проблема может быть решена путем введения в жидкии сплав малых количеств примесеи, снижающих межфазное натяжение на границе дисперсных частиц микрогетероогенного расплава (это натяжение определяет термическую стабильность частиц) [25]. В этом случае мы имеем дело с модифицированием структуры расплава, которая может улучшить качество литого металла.

В следующих разделах мы рассматриваем детальные результаты практического применения температурнои обработки жидких сплавов.

\section{ВЛИЯНИЕ ГОМОГЕНИЗИРУЮЩЕЙ ТЕРМООБРАБОТКИ РАСПЛАВА НА СТРУКТУРУ И СВОЙСТВА СЛИТКОВ И ОТЛИВОК ИЗ АЛЮМИНИЕВЫХ СПЛАВОВ}

Исследование влияния термообработки исходного расплава на структуру и своиства сталей начали в 1970-е гт. Б. Баум с сотрудниками [1]. Они были первыми учеными, использовавшими зависимости своиств от температуры для определения характеристических температур нагрева жидкого металла. Поскольку эти и последующие их результаты обобщены в [1, 2], в даннои статье мы ограничимся результатами изучения влияния термообработки расплавов на строение и своиства сплавов на основе алюминия с различными типами диаграмм состояния [3].

\section{Алюминиевме сплавы с простой эвтектикой}

Детальное исследование температур структурных перестроек в расплавах алюминий-кремний, являющихся основоИ промышленных силуминов, было начато денситометрическими исследованиями [26]. Было показано, что, если компоненты образща эвтектического состава смешивались при $1450^{\circ} \mathrm{C}$, на температурнои зависимости плотности, полученнои при охлаждении от этои температуры, никаких аномалии, которые могли бы быть ассоциированы со структурными перестроиками в расплаве, не отмечается (рис. 10a). Однако значения плотности, полученные после затвердевания и повторного расплавления образцов, оказываются примерно на $1 \%$ ниже, чем перед затвердеванием (рис. 106). В температурном интервале между 950 и $1110^{\circ} \mathrm{C}$ авторы наблюдали аномальное уменышение коэффициента термического расширения $\alpha$, после чего кривая $d(T)$ сливается с кривои охлаждения исходного расплава и не имеет в дальнеишем никаких специфических особенностеи при любых вариациях температуры в интервале от эвтектическои температуры до $1450^{\circ} \mathrm{C}$. Подобные аномалии, но при несколько других температурах также наблюдались для образцов с составом, отличным от эвтектического.

Различие между кривыми своиство-температура, полученными при нагреве до- и заэвтектических расплавов $\mathrm{Al}-\mathrm{Si}$ до $1200-1400^{\circ} \mathrm{C}$, было обнаружено и при исследовании их вязкости $v$ [27]. Интересно, что в области температур, лежащей ниже точки ветвления, кривые нагрева $v(T)$ для доэвтектических составов идут выше кривых 

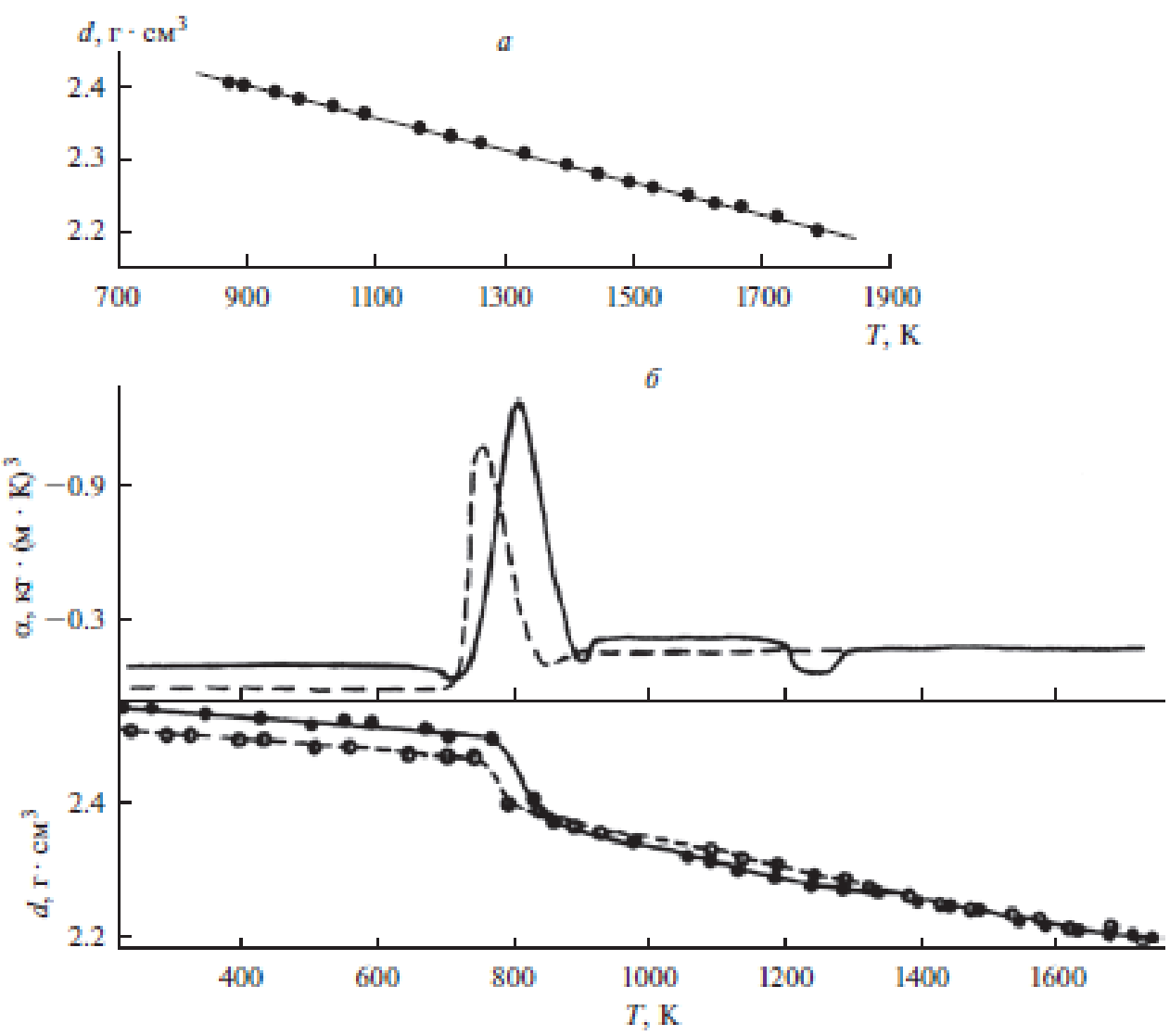

Pмс. 10. (а) Температурные зависимости плотности, полученные при охлакдении расплава Al-Si энтектиреского состана, приготонленного при $1450^{\circ} \mathrm{C}$ и (6) температурные занисимости плотности и козффициентв

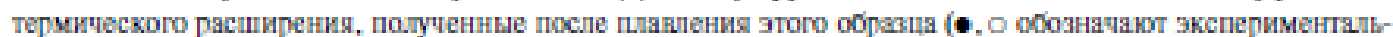
ные данные, полученные при нагрене и охлаждении этого образца соответственно; линии представлюют соФоһ сглаживающй сплаян и его произвонную).

охлаждения. После прохождения эвтектическои концентрации наблюдается инверсия гистерезиса вязкости: вязкость при охлаждении превышает вязкость при нагреве.

Полученные результаты были интерпретированы авторами на основе концепции наследственнои метастабильнои микрогетерогенности жидких эвтектических сплавов, т.е. аномалии кривых $d(T)$ и v(T) были объснены необратимыми переходами микрогетерогенного расплава, образовавшегося после плавления образцов, в состояние истинного раствора. Нанеся точки аномалии плотности и вязкости на фазовую диаграмму системы $\mathrm{Al}-\mathrm{Si}$, определили температурно-концентрационные границы области, в которои реализуются микрогетерогенные состояния жидких силуминов (рис. 11). Отсутствие ветвления температурных зависимостеи вязкости для образца эвтектического состава привело авторов к заключению, что необратимые изменения вяззкости связаны прежде всего с разрушением дисперсных частиц, сформированных из фрагментов первичнои фазы исходного слитка. Состав этои фазы изменяется при прохождении через точку эвтектики, что и приводит к инверсии гистерезиса вязкости.

Для того, чтобы исследовать влияние гомогенизирующеи термообработки расплава (ГТОР) на структуру закристаллизованных образцов при различных скоростях охла- 


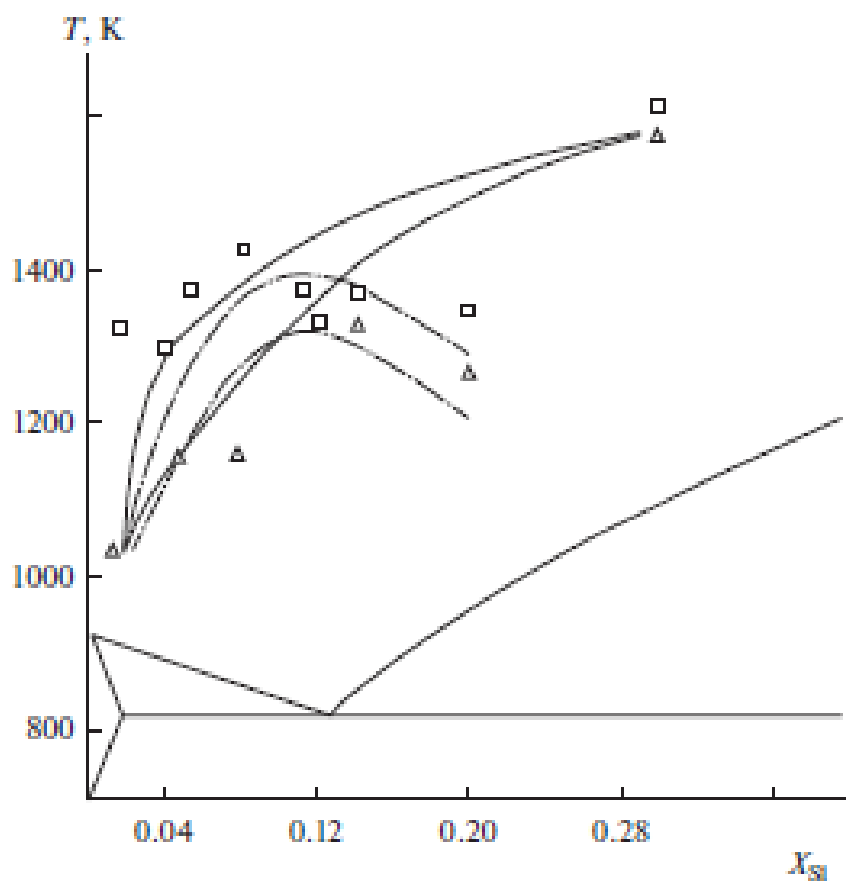

Pис. 11. Купол распала метастабитьноя микрогетерогенности в расплавах Al-Si, построенныя с использонанием температурних занисимостеи плоности $d(\cdots)$, кинемзтическои вхзкости v ( $\Delta)$ и удельного электросопротинтения $\rho$ (口).

ждения мы использовали [3] общепринятые процедуры закалки из жидкого состояния, обеспечивающие возможность нагрева расплавов до высоких температур, его охлаждения со скоростями в интернале $10^{2}-10^{60} \mathrm{C} / \mathrm{c}$ с параллельным контролем температуры в большинстве случаев.

Эти опыты были проведены с завтектическим силумином, содержашим 17 мас. \% Si [26]. Экспериментальные данные, характеризующие структурное состояние этого расплава, определенно указывают на то, что после плавления он является микрогетерогенным и, следовательно, имеются предпосылки для управления его структурои посредством гомогенизирующеи термообработки. Образцы сплава $\mathrm{Al}-17 \mathrm{Si}$ (мас. \%) были получены с использованием различных технологии: путем литья в графитовую форму $\left(V<100^{\circ} \mathrm{C} / \mathrm{c}\right)$ и закалкои из жидкого состояния $\left(V-10^{2}-10^{40} \mathrm{C} / \mathrm{c}\right)$. Интервал температур перегрева составлял $100-500^{\circ} \mathrm{C}$.

На рис. 12 приведены структуры, которые были зафиксированы после кристаллизации с различными скоростями расплава, подвергнугого гомогенизирующей термообработке с нагревом над ликвидусом до $1200^{\circ} \mathrm{C}$ и без такои обработки. Их сопоставление показыпает, что после гомогенизирующей термообработки в структуре закристаллизованного металла исчезают первичные кристаллы кремния и вся структура становится квазиэвтектическои, хотя концентрация кремния в нем превышает эвтектическую на $5 \%$ (рис. $12 \varepsilon, 12 z$ ). Если скорость охлаждения увеличить до $10^{6 \circ} \mathrm{C} / \mathrm{c}$, то после гомогенизирующего перегрева расплава в структуре кристаллических образцов на фоне глобулярнои эвтектики отчетливо проявляются первичные дендриты $\alpha$-твердого раствора, т.е. заэвтектический сплав начинает кристаллизоваться как доэвтектический.

Следовательно, гомогенизирующая термообработка расплава может рассматриваться как причина глубокого переохлаждения на фронте кристаллизации и после ее 


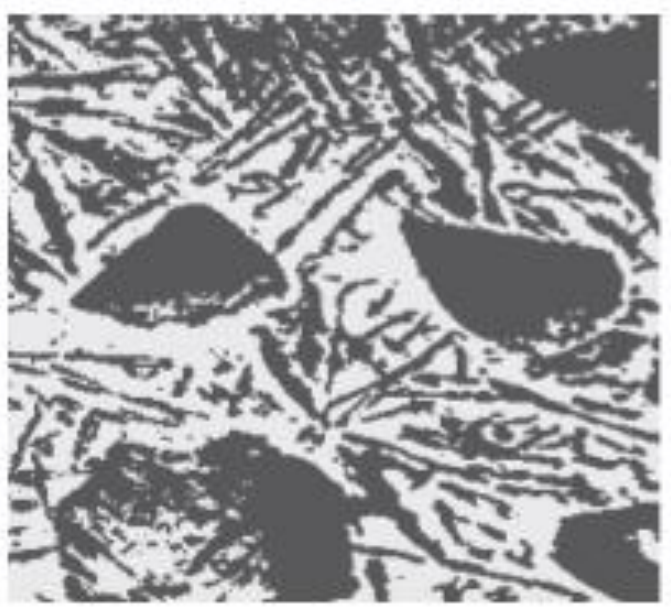

$\theta$

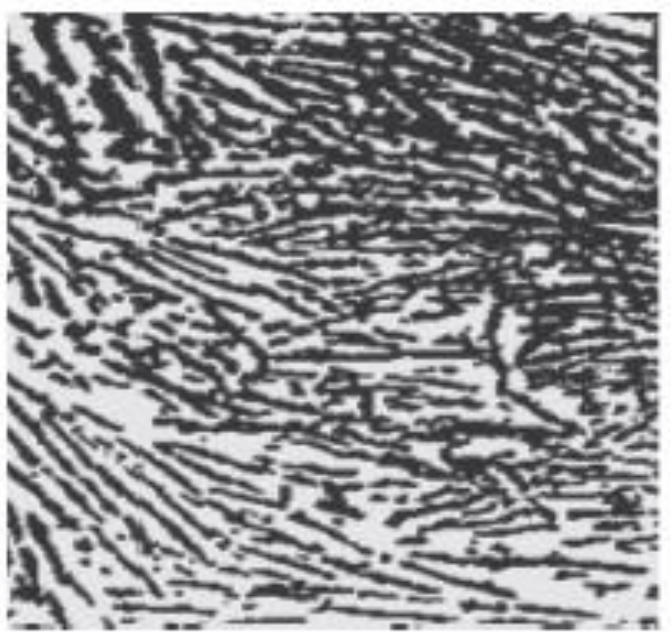

6
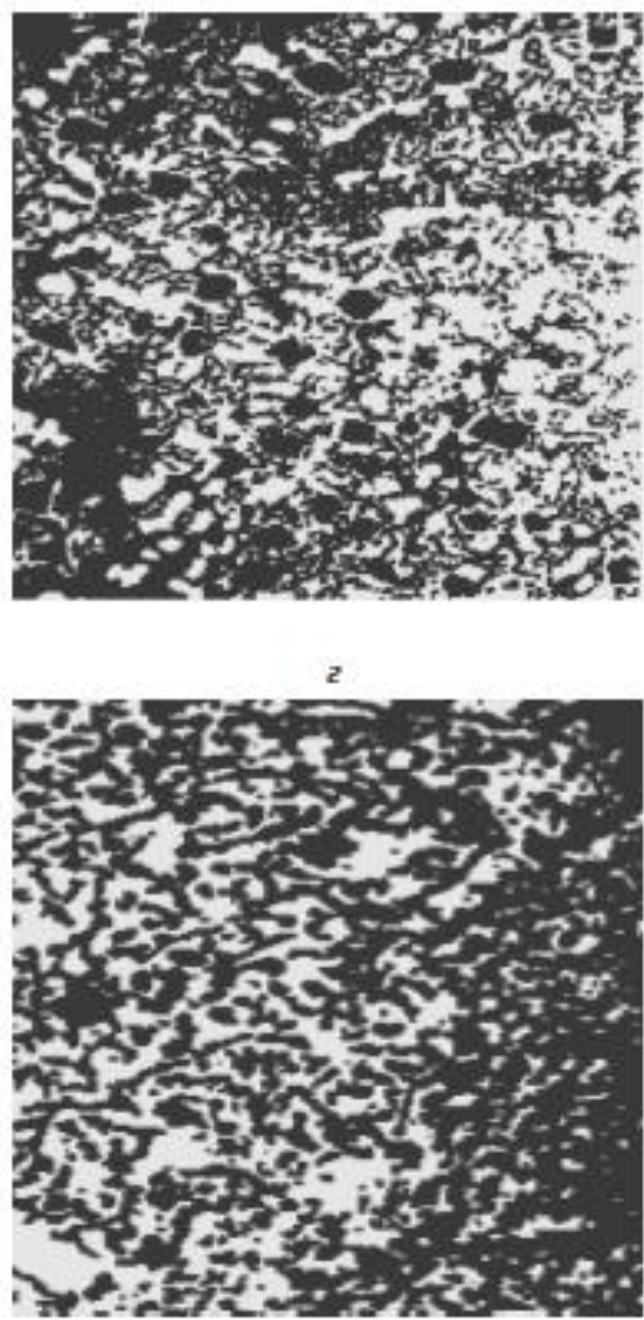

Pис. 12. Структура сплана $\mathrm{Al}-17$ ат. \& Si, нынтанленного без томогенизирукщцего перетрева и закристаллизонанного со скоростими (a) $10^{2}$ и (6) $10^{5 \circ} \mathrm{C} / \mathrm{c}$, и после гомогенизиру ицеи термическои обработки в жицком состовнии и кристалиизации со скоростими $(\sigma) 10^{2}$ и (z) $10^{5} \mathrm{C} / \mathrm{c}(\times 200)[26]$.

применения стабильная фазовая диаграмма сплава преврашается в метастабильную даже при обычных скоростях затвердевания. Сочетание высоких темпов охлаждения и ГТОР приводит к дальнеишему изменению фазовои диаграммы, а именно к появлению первичных кристаллов $\alpha$-твердого раствора в сплавах с первоначально заэвтектических составом.

\section{Аломиниевые сплавм с соединениями}

Влияние термообработки исходньх расплавов и скорости охлаждения на структуру слитков было исследовано для многих сплавов на основе алюминия с соединениями ( $\mathrm{Al}-\mathrm{Zr}, \mathrm{Al}-\mathrm{Ti}, \mathrm{Al}-\mathrm{Mn}, \mathrm{Al}-\mathrm{Mg}, \mathrm{Al}-\mathrm{Sc}$ и др.) [3]. Наиболее подробно недавно была изучена система $\mathrm{Al}-\mathrm{Cu}[28-30]$. 
Рассмотрим типичные эффекты на примере сплавов $\mathrm{Al}-\mathrm{Zr}$. Эта система была первои, для которои были определены характеристические температуры структурных перестроек в жидком состоянии.

Bo-первых, в [31] мы изучили температурные зависимости плотности и вязкости образцов, содержащих до 1.5 мас. \% $\mathrm{Zr}$ и приготовленных из реагентов высокои чистоты (иодидного $\mathrm{Zr}$ и $\mathrm{Al}$ с содержанием примесеи не более 0.001\%). Результаты, представленные на рис. $13 a$, показывают, что в температурном диапазоне от ликвидуса до $1800^{\circ} \mathrm{C}$ только в образце с минимальным содержанием циркония вблизи $1600^{\circ} \mathrm{C}$ наблюдаются признаки завершения перехода системы в состояние истинного раствора. Для более высоких конщентрации второго компонента этот переход не завершается вплоть до наивысшеи температуры исследуемого диапазона, о чем свидетельствует отсутствие совпадающих частеи кривых $d(T)$, полученных при нагреве и последующем охлаждении. Этот вывод был также подтвержден результатами вискозиметрического исследования, в котором были изучены сплавы указаннои выше чистоты, содержащие до 2 ат. \% Zr. В диапазоне температур до $1820 \mathrm{~K}$ не обнаружено никаких признаков необратимых изменении в структуре расплава.

Однако при изучении температурныдх зависимостеи вязкости лигатуры $\mathrm{Al}-2 \mathrm{Zr}$ (мас. \%) промышленнои чистоты были получены довольно нетривиальные результаты, свидетельствующие о сложности процессов, сопровождающих повышение температуры образца На начальном участке этои кривои (приблизительно до $1050^{\circ} \mathrm{C}$ ) значения вязкости увеличиваются при нагревании (рис. 13б). Затем темп роста у замедляется и, наконец, устанавливается "нормальныя" режим уменышения вязкости с повышением температуры. Эта высокотемпературная зависимость сохраняется при дальнеишем охлаждении, а ниже $1200^{\circ} \mathrm{C}$ кривая $v(T)$ отклоняется от кривои, полученнои при начальном нагреве. Судя по представленным здесь результатам, образец коммерческои чистоты переходит в состояние истинного раствора вблизи $1230^{\circ} \mathrm{C}$, т.е. при гораздо более низкои температуре, чем точка гомогенизации аналогичного сплава, выплавленного из высокочистых компонентов. Этот факт стал отправнои точкои в формировании идеи модифицирования расплавов специально подобранными добавками для снижения температуры их гомогенизации.

Для того, чтобы исследовать влияние термическои обработки и скорости охлаждения расплава на структуру сплавов $\mathrm{Al}-\mathrm{Zr}$, были изучены образцы заперитектических композиции, содержащие $0.6,1.5,2.0,3.0$ и 4.7 мас. \% $\mathrm{Zr}$. Установлено, что при низком перегреве расплава $(\Delta T<150 \mathrm{~K})$ и низких скоростях охлаждения, независимо от концентрации второго компонента, в отливке в соответствии с равновеснои фазовои диаграммои образуется интерметаллическое соединение $\mathrm{Al}_{2} \mathrm{Zr}$ с тетрагональнои кристаллическои решеткои пространственнои группы $\mathrm{D}_{23}$. Наиболее типичнои формои роста его кристаллов являются ограненные удлиненные пластины (рис. 14a), размер которых уменышается с ростом скорости охлаждения. По мере увеличения концентрации $\mathrm{Zr}$, распределение этих кристаллов по сечению образца становится все более неравномерным, и их среднии размер увеличивается с 60 до 250 мкм. Интерметаллические соединения этои модификации устоичиво растут при скоростях охлаждения, меньших чем $10^{2 \circ} \mathrm{C} / \mathrm{c}$ для $\mathrm{Al}-1.5 \mathrm{Zr}$ (мас. \%), $10^{3 \circ} \mathrm{C} / \mathrm{c}$ для $\mathrm{Al}-2 \mathrm{Zr}$ (мас. \%), $10^{4 \circ} \mathrm{C} / \mathrm{c}$ для $\mathrm{Al}-3 \mathrm{Zr}$ (мас. \%) и $10^{5 \circ} \mathrm{C} / \mathrm{c}$ для $\mathrm{Al}-4.7 \mathrm{Zr}$ (мас. \%).

Исследовано влияние строения исходного расплава на размер, морфологию и структуру алюминида в спларе $\mathrm{Al}-2 \mathrm{Zr}$ (мас. \%) [32, 33]. Исходная жидкость была перегрета до различных температур $\left(\Delta T-100-460^{\circ} \mathrm{C}\right)$. Изменение формы стабильных включении алюминида циркония в зависимости от скорости охлаждения $V$ и перегрева над ликвидусом $\Delta T$ показано на рис. 15 (области I и II). Рис. 146 иллюстрирует типичныи случаи, когда вместо пластин образуются дендритные кристаллы с четко очерченными вершинами ветвеи первого и второго порядка. Следует обратить внима- 

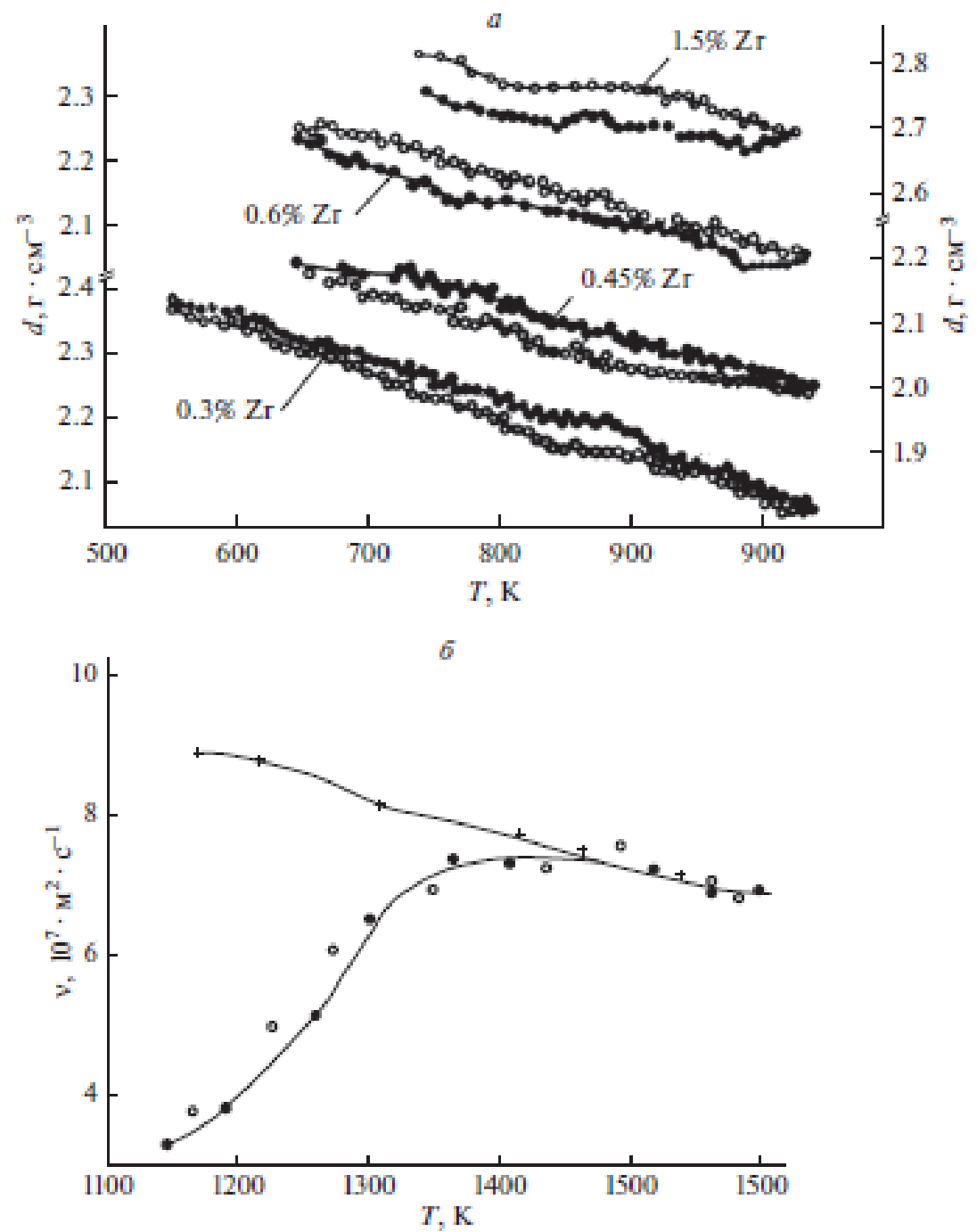

Pис. 13. (а) Темперапурные занисимости плотности распланов $\mathrm{Al}-\mathrm{Zr}$ ( $\circ-$ нарев, $\bullet-$ охлаждение; концен-

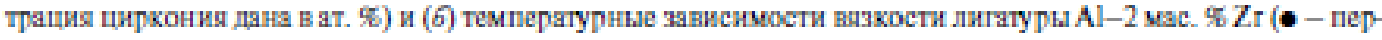
ныя натрев, + - охлаждение, о - повторныя нагрев после затверденания).

ние на формирование гораздо более дисперсных равноосных дендритов, имеющих специфическую лепестковую структуру; их морфология и размеры однозначно доказывают их первичное происхождение. Для каждого состава существует определенныи диапазон скоростеи охлаждения, в котором формируются первичные интерметаллиды подобнои морфологии, структуры и размеров.

Рентгеновскии фазовыи анализ таких кристаллов показал, что они имеют состав $\mathrm{Al}_{3} \mathrm{Zr}$ и кубическую упорядоченную структуру, аналогичную вторичнои метастабильнои фазе, зарождающеися в процессе распада пересыщенного $\alpha$-трердого раствора. По мере увеличения концентрации $\mathrm{Zr}$ в сплаве условия для наиболее устоичивого роста интерметаллических соединении этои метастабильнои модификации смещаются в сторону более высоких скоростей охлаждения. Исследовано влияние первичного пе- 

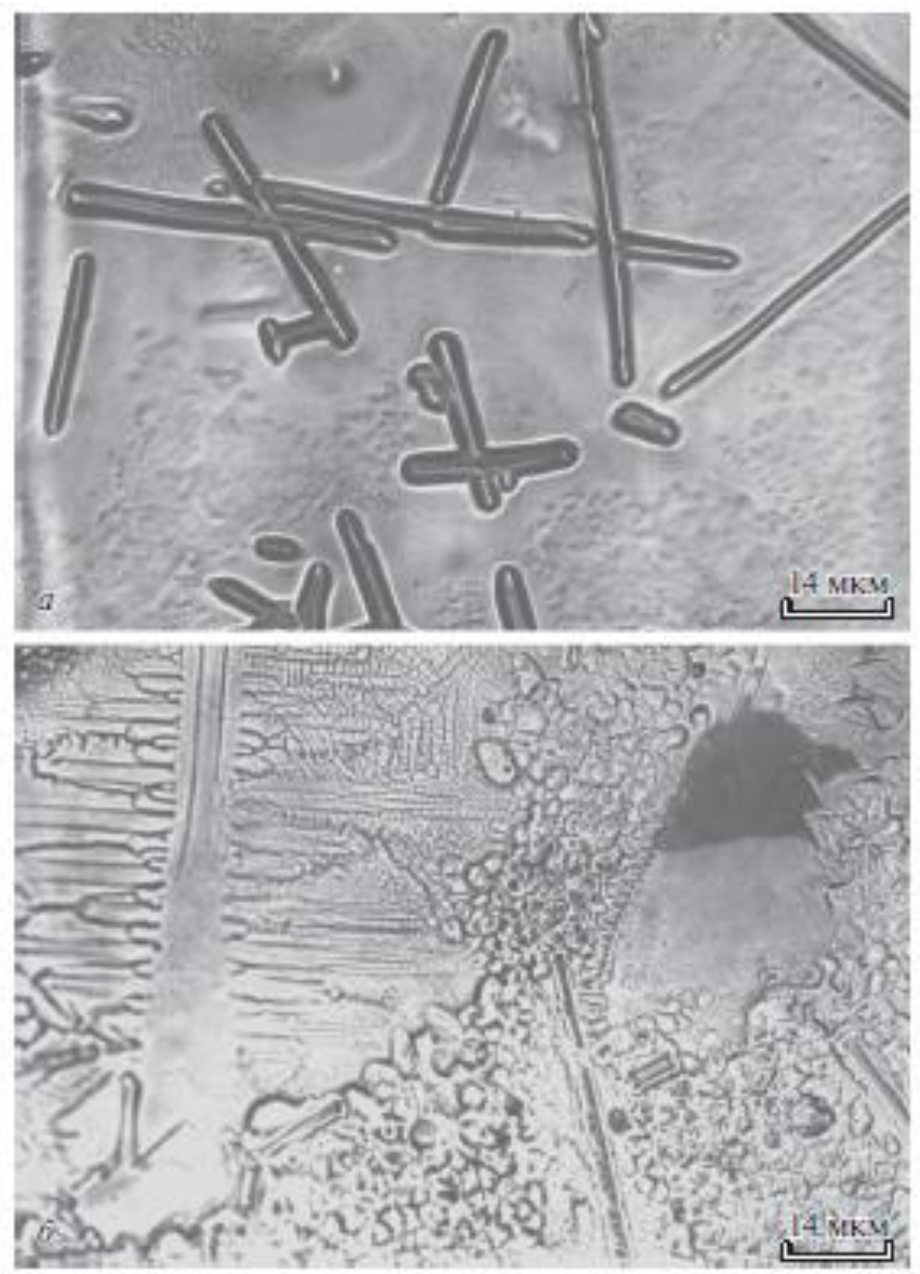

Pис. 14. Формы роста кристалтон апюминида циркония (стуктура типа D023) в зависимости от параметров затвердевания пля сплана Al-2 мас. $\& \mathrm{Zr}$; (a) $V-10 \mathrm{~K} / \mathrm{c}, \Delta T-200 \mathrm{~K}$; (6) $V-10^{3} \mathrm{~K} / \mathrm{c}, \Delta T-360 \mathrm{~K}$.

регрева расплава на морфологическую устоичивость форм роста метастабильных алюминидов. Установлено, что при $\Delta T-100^{\circ} \mathrm{C}$ они растут в виде ограненных кристаллов кубическоя формы (рис. 16, область Г' на рис. 15). При высокоя $\Delta T$ дендритные формы становятся доминирующеи формоЯ роста кристаллов (область II' на рис. 15). При $\Delta T-200-250^{\circ} \mathrm{C}$ интерметаллиды имеют максимальныи размер до 10 мкм и растут в виде дендритов с ярко выраженнои анизотропиеи скоростеи роста первичнои и вторичнои ветвеи (рис. 16б). При $\Delta T-400^{\circ} \mathrm{C}$ размер кристаллов уменышается до 5 мкм и они принимают форму симметричных дендритов (рис. $16 \theta$ ). Нагревание выше температуры гомогенизашии сопровождается резким увеличением количества алюминидов и дополнительным уменьшением их размера до 1-2 мкм (Заштрихованная область на рис. 15). Таким образом, изменяя условия подготовки расплава, мы можем в широких интервалах изменять размер и морфологию кристаллов метастабильнои фазы $\mathrm{Al}_{3} \mathrm{Zr}$.

Позже подобные результаты были получены при исследовании алюминидов в сплавах Al-Ti, $\mathrm{Al}-\mathrm{Fe}, \mathrm{Al}-\mathrm{Mn}$ и $\mathrm{Al}-\mathrm{Sc}$. Обнаружены следуюшие общие закономерности:

- Устоичивои формои роста кристаллов при низких скоростях охлаждения и низких перегревах расплава является ограненная форма. Наиболее широкая область огра- 


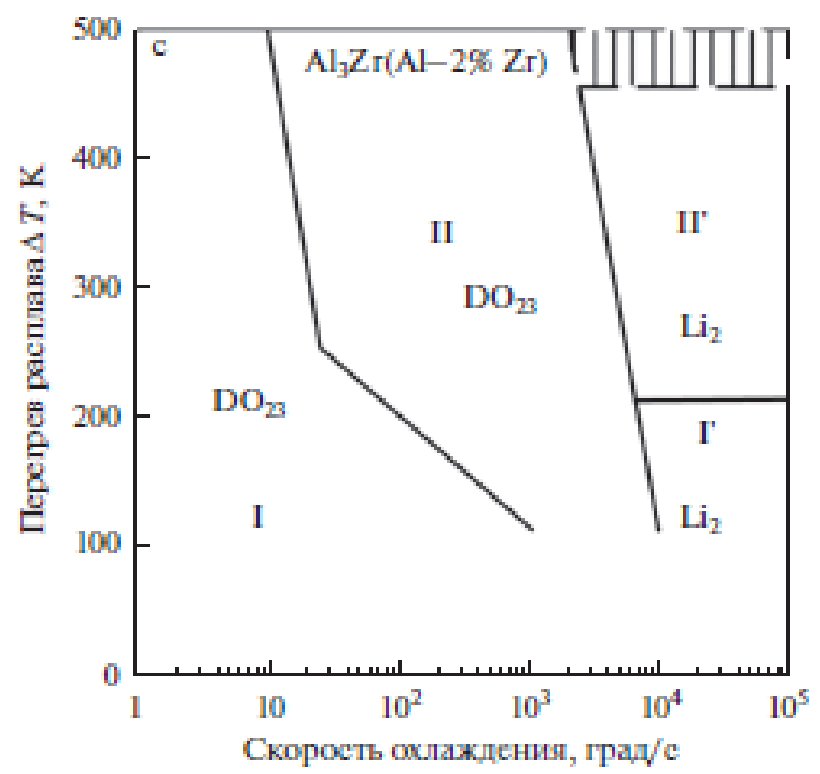

Рмс. 15. Области роста кристаллов с разтичнои морфологиеи атюминидов циркония (I-ограненные кристаллы; II - дендритные кристачты).

ненных кристаллов образуется при росте алюминида скандия, тогда как самая узкая зона соответствует росту алюминида железа.

- С ростом скорости охлаждения и перегрева расплава наблюдается переход от ограненных к закругленным (древовидным, сферолитным или глобулярным) формам роста. Сферолитные формы встречаются в процессе затвердевания алюминидов $\mathrm{Al}_{3} \mathrm{Fe}$ и $\mathrm{Al}_{6} \mathrm{Mn}$, в то время как глобулярные формы обнаруживаются при формировании алюминидов $\mathrm{Al}_{3} \mathrm{Sc}$.

- Перегрев расплава в сочетании с быстрои закалкои приводит к образованию метастабильных фаз $\mathrm{Al}_{3} \mathrm{Zr}, \mathrm{Al}_{3} \mathrm{Ti}$ и $\mathrm{Al}_{6} \mathrm{Fe}$.

Приведенные выше результаты соответствуют перегреву расплава до температуры, лежащей ниже температуры гомогенизации $T_{\mathrm{ham}}$. Результаты металлографического исследования, изучения рентгеновскои дифракщии и спектрального рентгеновского анализа лент, подготовленных из сплава $\mathrm{Al}-0.6 \mathrm{Zr}$ (мас. \%), представлены на рис. 17. Было показано, что ленты, которые были получены из расплава, перегретого до $1150^{\circ} \mathrm{C}$, имеют более дисперсную структуру, чем ленты, полученные после его перегрева до $1220^{\circ} \mathrm{C}$. Можно заметить отчетливое снижение количества первичных выделении метастабильнои фазы $\mathrm{Al}_{3} \mathrm{Zr}$, расположенных в центрах модифицированных зерен $\alpha$-твердого раствора, и укрупнение этих зерен с увеличением температуры литья (рис. 17a, 17б). Перегрев расплава в область температур, близких к $T_{\text {hom }}$, изменяет фазовыи состав расплава, и в результате вместо равновеснои гетерогеннои двухфазнои структуры формируется метастабильныи однофазныи аномально пересыщенныи $\alpha$-твердыи раствор (рис. 17s). Дополнительная выдержка расплава при такои температуре, а также охлаждение при пониженнои температуре литья не приводят к качественным изменениям в структуре сплава.

Положительная роль гомогенизирующей термической обработки расплава при создании однофазных структур аномально насыщенного $\alpha$-твердого раствора с переходными металлами подтрерждается результатами, полученными при упрочнении сплава 

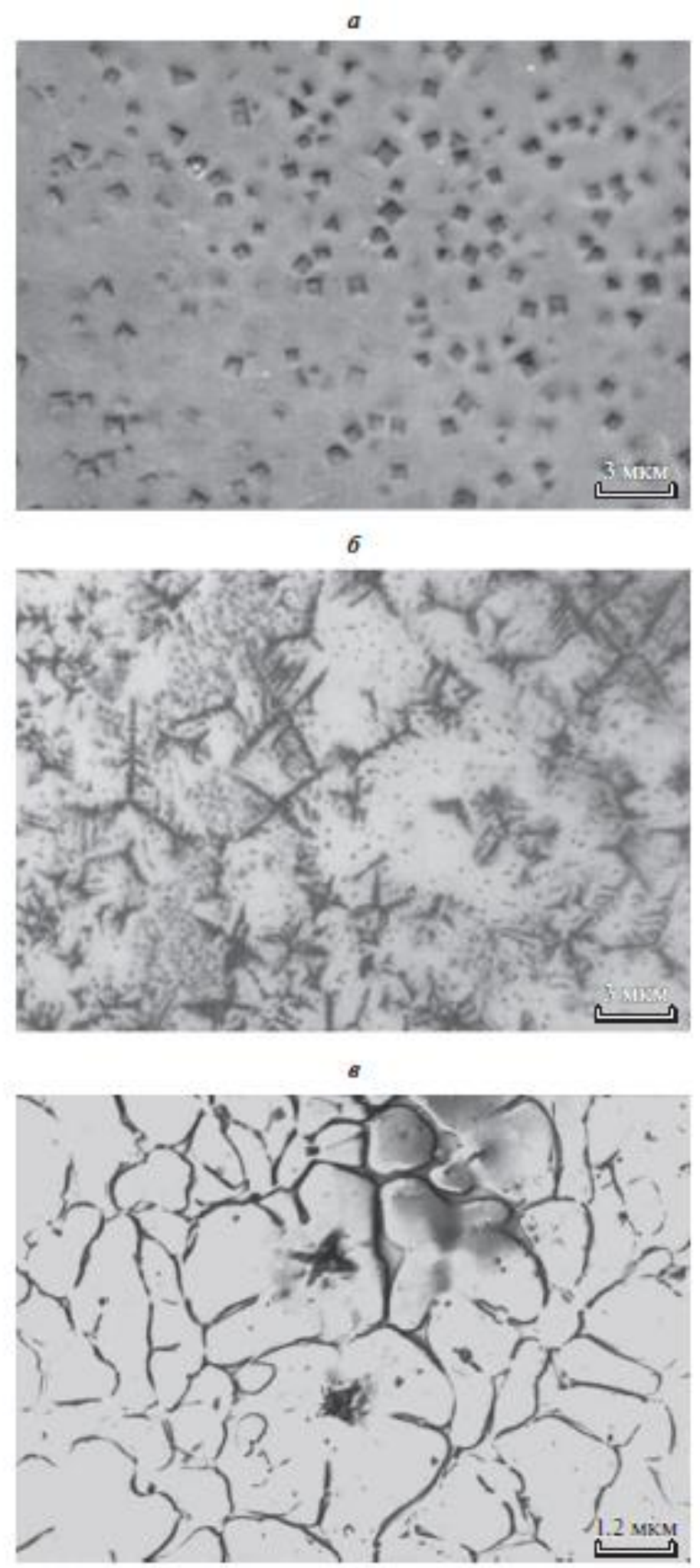

Pмс. 16. Трансформация форм роста кристаллов алюминида циркония (структура типа $\mathrm{Ll}_{2}$ ) в зависимести от перегрева исходного расплава $\left(V-10^{4} \mathrm{~K} / \mathrm{c}\right)$ : (a) $\Delta T-100 \mathrm{~K}$; (6) $\Delta T-300 \mathrm{~K}$; $(e) \Delta T-450 \mathrm{~K}$. 

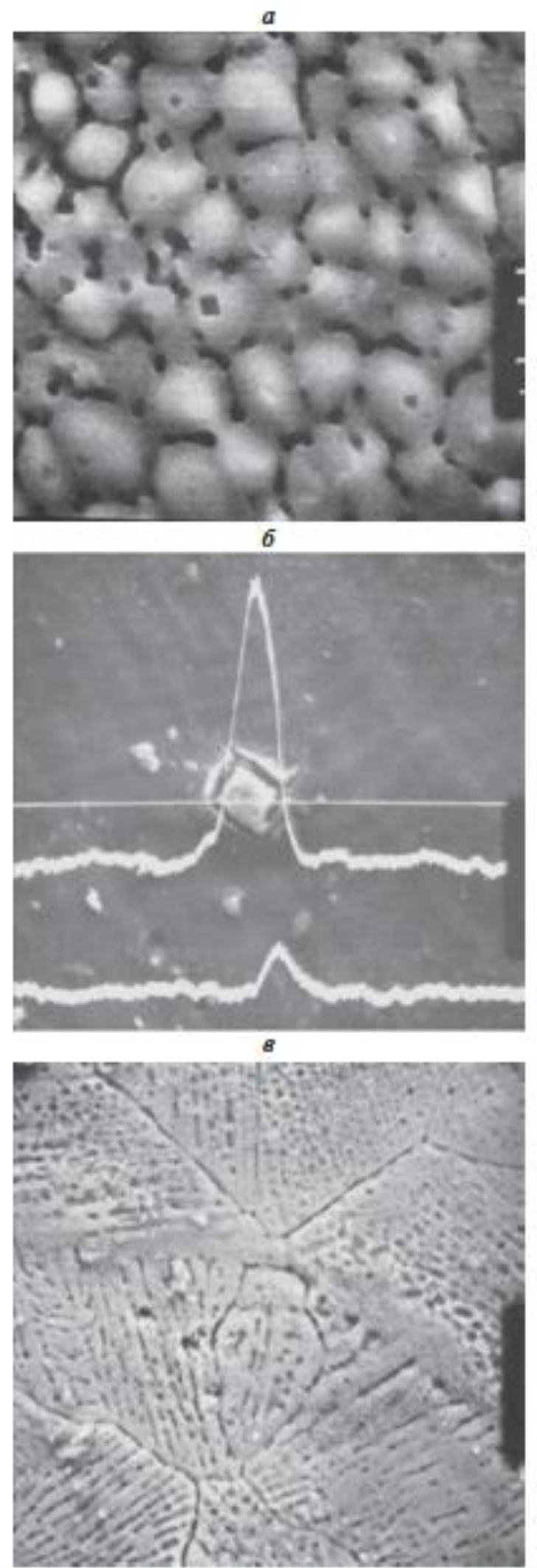

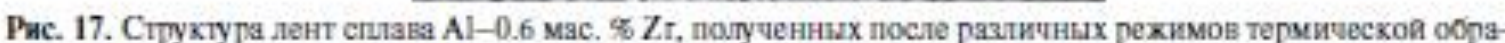
ботки исходного раслиава: снимок в обратно рассеянных электронах и снимок в ренттеновском $K_{\alpha}$-изуучении; $a, 6-T<T_{\text {hom }: \sigma-T}>T_{\text {hom }}$ 
с более высоким содержанием Zr. Например, для сплава Al-2Zr (мас. \%) такая структура образуется в лентах, получаемых при быстрои закалке со скоростью охлаждения $V-10^{4 \circ} \mathrm{C} / \mathrm{c}$. В то же время, если расплав не подвергался предварительнои гомогенизирующеи термообработке, подавление первичнои кристаллизации алюминидов в сплаве происходит при охлаждении со скоростями порядка $10^{5 \circ} \mathrm{C} / \mathrm{c}$.

Описанные выше закономерности изменения структуры были также обнаружены при кристаллизации сплавов $\mathrm{Al}-\mathrm{Ti}$ заэвтектического состава.

Таким образом, применение гомогенизирующеи термическои обработки расплавов при кристаллизации сплавов алюминия с переходными металлами расширяет область существования аномально перенасыщенного $\alpha$-твердого раствора на основе Al вследствие подавления роста первичных алюминидов и формирования однофазного состояния при более низких темпах охлаждения.

Сплавы алюминия с медью по сравнению с перечисленными выше сплавами с соединениями имеют наиболее сложную диаграмму состояния. На неи имеется две горизонтальные линии, соответствующие эвтектическим превращениям и пить горизонталеи с перитектическими превращениями. Кроме того, присутствуют шесть эвтектоидных и семь перитектоидных реакщия. Всего в этои системе существует пятнадцать фаз. Две из них являются твердыми растворами на основе $\mathrm{Cu}$ и $\mathrm{Al}$, шесть фаз образуются с участием жидкои фазы, остальные образуются в результате превращении в трердом состоянии. Авторы [29] исследовали плотность 17 сплавов $\mathrm{Al}-\mathrm{Cu}$ различнои концентрации, болышинство из которых различаются фазовыми составами при температурах, соответствующих началу плавления. В системе со столь контрастными по плотности компонентами вероятным представлялось осаждение более плотных дисперсных частиц, обогащенных медью, в менее плотнои дисперсионнои среде, богатои алюминием, и, наоборот, всплытие обогащенных алюминием частиц в среде, богатои медью. В гамма-плотномере пучок излучения просвечивал исследуемые образцы вблизи дна тигля, где концентрация меди могла существенно превышать расчетную конщентрацию, задаваемую при шихтовке. Поэтому при выяснении условия гомогенизации расплавов было решено строить температурные зависимости не плотности $\rho$, а произведения $\rho \mu$, где $\mu$ - массовыи коэффициент ослабления пучка, зависящии от локального состава просвечиваемои зоны.

Наиболее общеи чертои полученных зависимостеи $\rho \mu(T)$ является расхождение ветвеи нагрева и охлаждения (гистерезис), свидетельствующее о необратимых изменениях состава и строения просвечиваемои зоны большинства изученных бинарных расплавов после их нагрева выше точки ветвления этих кривых (рис. 18). Наиболее выразительно гистерезис произведения $\rho \mu$ проявляется для образщов, обогащенных алюминием, где расхождение ветреи нагрева и охлаждения достигает 16\%. Как и в [28], где отмечалось ветвление температурных зависимостей вязкости сплавов $\mathrm{Al}-\mathrm{Cu}$, авторы [29] связали это явление с необратимым разрушением метастабильного микрогетерогенного состояния расплавов, унаследованного от гетерогенных исходных кристаллических образцов. Аномально болышие различия в зафиксированных значениях комплекса $\rho \mu$ для сплавов, богатых алюминием, могут быть объяснены только осаждением более плотных дисперсных частиц, обогащенных медью, в расплаве меньшей плотности.

Наиболее неожиданным результатом денситометрических опьтов [29] явилось обнаружение гистерезиса температурных зависимостей $\rho \mu(T)$, полученных при плавлении гомогенных кристаллических образцов стехиометрических составов $\mathrm{CuAl}$ и особенно $\mathrm{CuAl}_{2}$. Ранее при исследовании температурных зависимостей плотности расплавленных тугоплавких соединения (бориды $3 d$-переходных металлов) не обнаруживалось подобного явления и кривые $\rho(T)$, полученные при нагреве и охлаждении расплава, совпадали. Мы рассматривали этот факт как дополнительное подтверждение наследственного происхождения гетерогенности расплавов. В случае же соедине- 

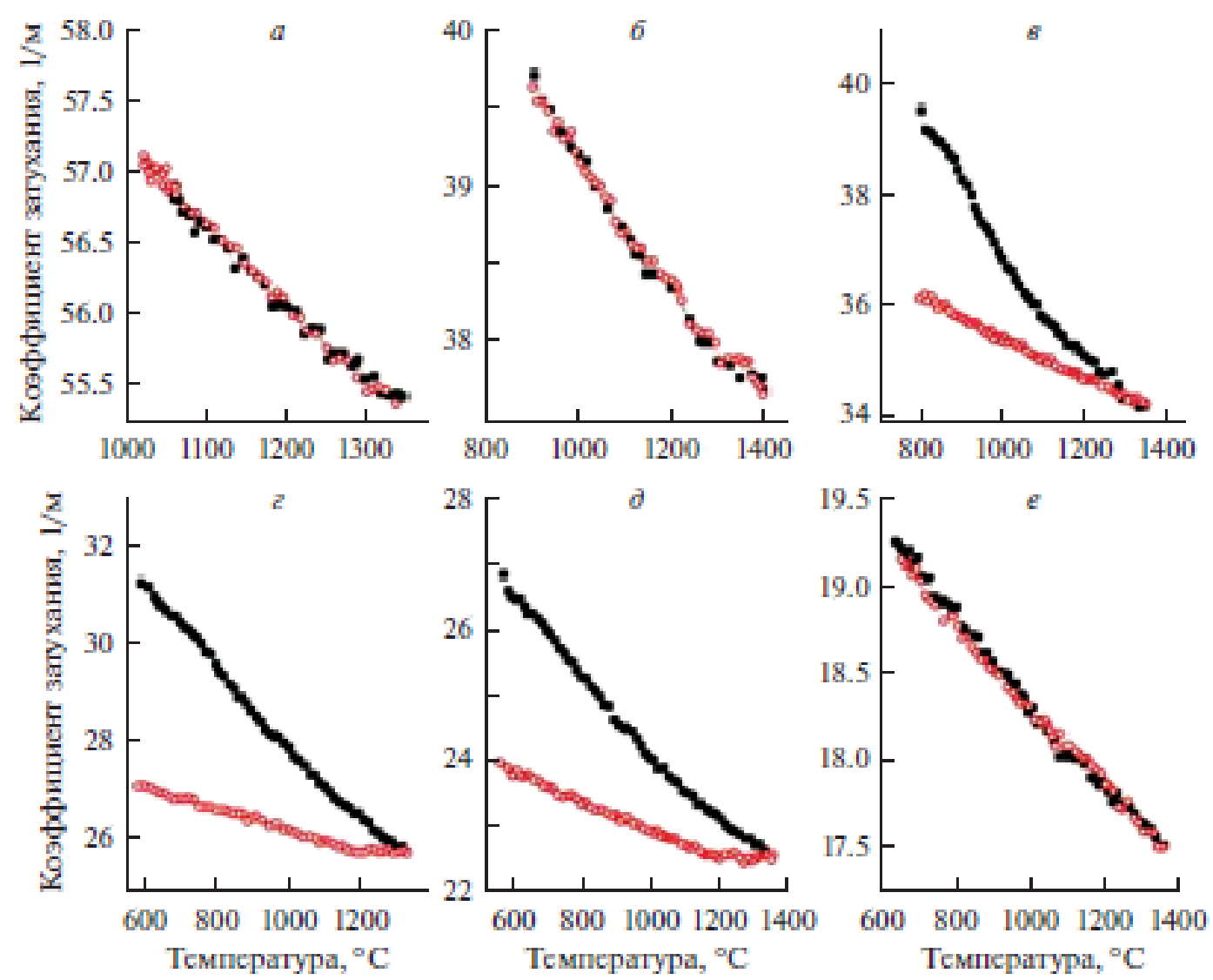

Рис. 18. Температурные занисимости произведения $\rho \mu$ некоторшх сплавов $\mathrm{Al}-\mathrm{Cu}=$ (a) $\mathrm{Al}_{5} \mathrm{Cu}_{95}$ ( $(6) \mathrm{Al}_{45} \mathrm{Cu}_{55}$. (б) $\mathrm{Al}_{55} \mathrm{Cu}_{45}$, (z) $\mathrm{Al}_{75} \mathrm{Cu}_{25}$, (d) $\mathrm{Al}_{83} \mathrm{Cu}_{17}$. (e) $\mathrm{Al}_{95} \mathrm{Cu}_{5}$ при нагрене (сплошние символы) и последующем охлаждении (пустие симноты).

ния CuAl и $\mathrm{CuAl}_{2}$ гистерезис $\rho \mu(T)$ не только существовал, но расхождение кривых и охлаждения было максимальным именно при стехиометрическои концентрации, уменышаясь по мере удаления от нее.

Оригинальное объяснение подобного явления мы нашли в работе Р.Е. Рыльцева и Л.Д. Сона [34]. По их данным, при плавлении сравнительно низкоплавких интерметаллических соединения, подобньх $\mathrm{CuAl}$ и $\mathrm{CuAl}_{2}$, в расплаве могут сохраняться прочные межатомные связи, своиственные наиболее тугоплавким интерметаллидам этои системы (в нашем случае $\mathrm{Cu}_{3} \mathrm{Al}$ ). На основе этих связей возможно формирование соответствующих дисперсных частиц интерметаллических фаз. Однако эта гипотеза нуждается в дополнительном подтверждении.

Проведены первые опыты по изучению влияния гомгенизирующеи термообработки расплавов $\mathrm{Al}-\mathrm{Cu}$ на структуру, формирующуюся после их кристаллизащии [30]. С этои целью были выплавлены образцы, содержащие 10, 17.1, 25 и 32 ат. \% Сu. Одна партия образцов нагревалась в жидком состоянии до $1400^{\circ} \mathrm{C}$, т.е. выше температуры их гомогенизации, а вторая (контрольная) не подвергалась такои обработке. После установления одинаковои температуры расплава $\left(720^{\circ} \mathrm{C}\right.$ они были закристаллизованы в установке центробежного литья в массивныи щелевои медныи кокиль и имели форму дисков толщинои 2.1-2.4 мм, что соответствует одинаковои расчетнои скорости охлаждения, близкои к $6 \cdot 10^{3}$ град/с. Исследование полученных кристаллических 
структур включало металлографическии и фазовыи анализ, измерения параметра решетки и микротвердости фазовых составляющих.

При сравнении структур, полученных при закалке указанньх образцов, обнаружены отчетливые различия морфологии кристаллических фаз. Кроме того, отмечено, что после гомогенизирующей обработки расплавов изменяется кинетика кристаллизации и, как следствие, соотношение фаз в структуре и содержание в них меди; стимулируется переход к метастабильнои кристаллизации и возрастает структурная неоднородность сплавов.

\section{Алюминиевме сплавы с монотектиками}

Так назыпаемые псевдо-сплавы с очень мелкими и однородно распределенными включениями одного из компонентов могут быть получены в системах с ограниченноИ смешиваемостью в жидком состоянии. Некоторые из них обладают уникальными служебными своиствами (демпфирующими, трибологическими и т.д.). Основная проблема их производства связана с тенденциеи к макроскопическому разделению при охлаждении и существенным обогащением нижнеи части слитка более плотным компонентом.

Известно, что макроскопическое расслоение таких жидкостеи может быть подавлено при их затвердевании в условиях невесомости или в скрещенных электрическом и магнитном полях [35]. В этом случае наблюдается довольно равномерное распределение компонентов по высоте с выделениями размером порядка 1000 мкм. В результате затвердевания жидкого металла при скорости охлаждения $10^{3}-10^{6 \circ} \mathrm{C} / \mathrm{c}$ в замонотектических сплавах может образоваться однородная структура с очень мелкими включениями [36]. Однако такие условия кристаллизации могут быть реализованы в промышленных технологических процессах только при получении металлических порошков или тонких лент, но не в крупномасштабном производстве массивных отливок.

Основываясь на положительном опыт, полученном для эвтектических сплавов, П.С. Попель и др. изучили возможность подавления или замедления макроскопического распада в массивньх образщах расслаивающихся алюминиевых сплавов с помощью их термическои обработки в жидком состоянии [37]. Признаки существования микрогетерогенности коллоидного масштаба в этих расплавах при небольшом перегреве над куполом макроскопическои несмешиваемости были отмечены в ультраакустических экспериментах и в опытах по дифракщии электронов [38], а также в исследовании малоуглового рассеяния рентгеновского излучения [39].

При измерении вязкости этих расплавов в процессе первичного нагрева авторы выявили аномально высокии разброс ее значении (до 10-15\%), которыи сохранялся до температур, специфичных для каждого состава. При дальнейем нагревании и последующем охлаждении стабильные значения вязкости наблюдались вплоть до границы области расслоения. По мнению авторов, наблюдаемая нестабильность значении v связана с тем, что при выходе за пределы купола несмешиваемости система переходит из макроскопически гетерогенного состояния в метастабильное микрогетерогенное типа микроэмульсии, которое, в свою очередь, разрушается при нагревании до указанных выше температур. В дальнейем эти температуры будем называть температурами гомогенизации расплавов $T_{\mathrm{hom}}$

Нанеся температуры, при которых значения вязкости стабилизировались, на фазовую диаграмму системы Al-In, авторы получили куполообразную кривую, ограничивающую область существования метастабильнои коллоиднои структуры (рис. 19). После этого влияние гомогенизирующеи термообработки расплавов на структуру, формирующуюся при их кристаллизащии с умеренными скоростями охлаждения (порядка $1^{\circ} \mathrm{C} / \mathrm{c}$ ) изучалось на образщах массои около $30 \mathrm{r}$, которые выплавлялись в открытои печи сопротивления. Было установлено, что для всех исследованных составов при 


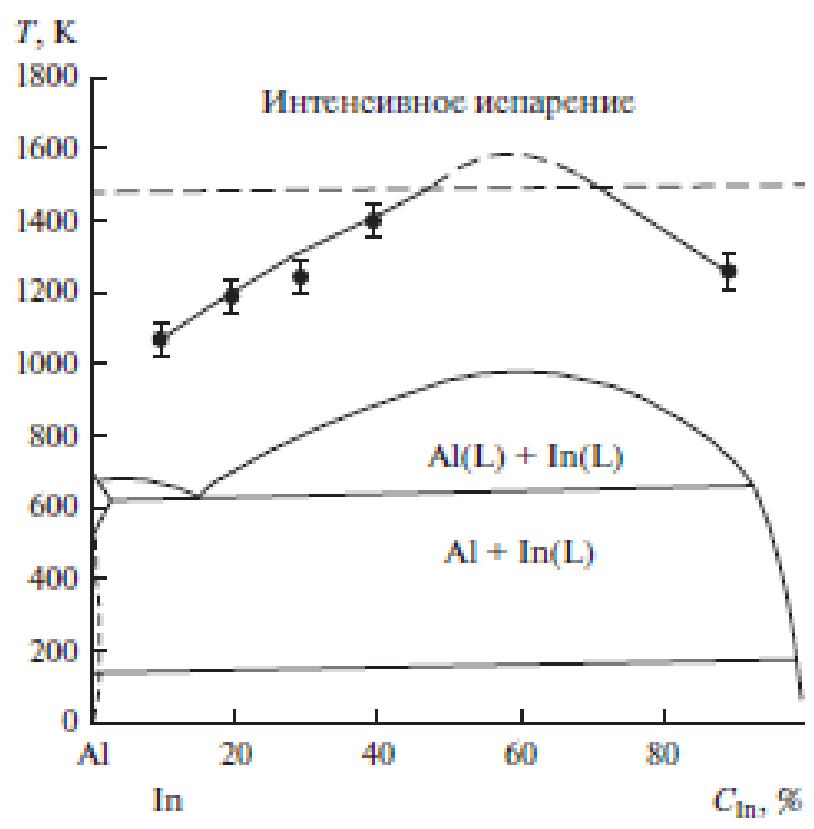

Pис. 19. Часть фазовоһ диаграммы и область существонания метастабитьнои микрогетерогенности системы Al-In.

температуре нагрева расплавов ниже купола микроскопического расслоения, показанного на рис. 19, в закристаллизованных образщах фиксируется четкая граница между фазами, обогащенными различными компонентами (рис. 20a). Рентгеновский фазовыи анализ подтвердил раздельное существование алюминия (вверху) и индия (внизу). Когда температура расплава поднимается и приближается к куполообразнои кривоИ микрорасслоения, эта граница размынается, а далее, при $T>T_{\text {høе }}$, макроскопическая сегрегащия в слитках подавляется полностью. В этом случае их структура становится аналогичноИ квазиэвтектике (рис. 206) и состоит из частиц индиевои фазы, равномерно распределенных по объему алюминиевои матрицы. Дальнеишее повышение температуры расплава существенно влияет на структуру слитка, способствуя измельчению дисперсных включений индиевои фазы в макроскопически однородном слитке.

Таким образом, в сплавах монотектических систем, затвердевших из расплава, подвергнутого предварительнои гомогенизирующеи термообработке, подавляется тенденция к макроскопическому расслоению, что позволяет получить отливки с включениями дисперсной индиевои фазы в макроскопически однородном слитке.

\section{Промыиленные алюминиевые сплавы}

В этом разделе широкие возможности эффективного использования термическои обработки расплава для управления структурои и своиствами в твердом состоянии иллюстрируются на примере ряда гранулированных и литеиных сплавов.

Известно, что жаропрочность сплавов $\mathrm{Al}-\mathrm{Zr}-\mathrm{Cr}$ обеспечивается тугоплавкими добавками, которые выпадают в виде дисперсных интерметаллических соединении при переработке гранул или лент в полуфабрикаты. Технология производства полуфабрикатов из гранулированных сплавов требует равномернои тонкои структуры в состоянии as cast. Эта задача усложняется, однако, наличием кристаллов первичных алюми- 


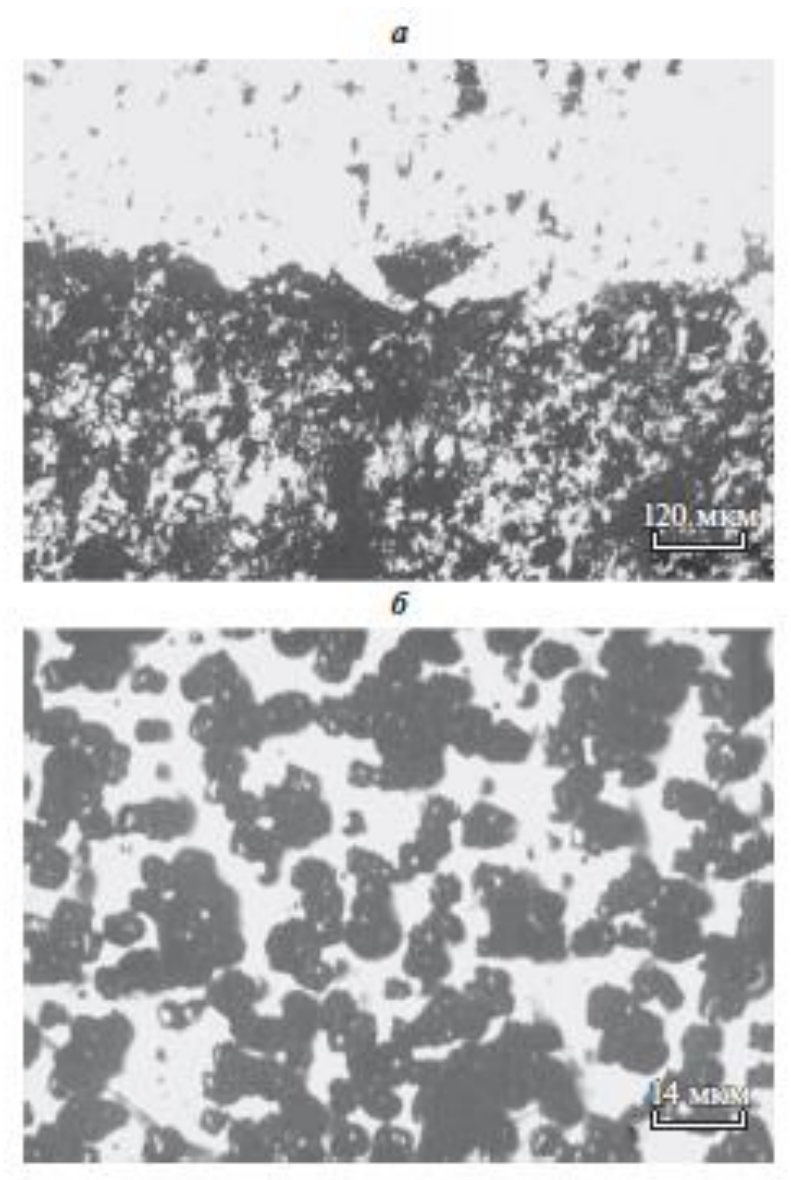

Pис. 20. Структура сплава Al-20 aт. \& In, закристаллизованного со скоростью охлаждения $V$ - I K/c от темпераур, лежапих (a) внутри области суцествования метастабильноя михрогетерогенности (перегрев наң ликнидусом $\Delta T-70 \mathrm{~K})$ и (6) за пределами этоя офласти $(\Delta T-600 \mathrm{~K})$.

нидов в литои структуре. Их присутствие, резко ухудшающее механические своИства сплавов, ответственно за низкую устоичивостыю переходных металлов в алюминии. Наиболее традиционным методом их устранения является использование технологии производства лент или порошков, в которых скорость охлажцения при закалке из жидкого состояния достигает $10^{4 \circ} \mathrm{C} / \mathrm{c}$ и более.

В нашем эксперименте мы использовали для тех же целеи термическую обработку исходных расплавов в качестве альтернативы их высокоскоростнои закалке. Было установлено, что для троиных сплавов $\mathrm{Al}-\mathrm{Zr}-\mathrm{Cr}$ с содержанием переходных металлов ниже $4.5 \%$ температуры гомогенизапии с лежат между 1230 и $1250^{\circ} \mathrm{C}$.

Было обнаружено появление в троиных сплавах метастабильнои модификации соединения $\mathrm{Al}_{3} \mathrm{Zr}$ при тех же условияг, что и в бинарньх аналогах $\mathrm{Al}-\mathrm{Zr}$. По мере роста перегрева расплава округлые кубические формы роста сменяются дендритными формами, отличаюшимися степенью анизотропии скоростей роста вторичных ветвеи. Предварительное нагревание расплава до температуры, близкои к температуре гомогенизации резко увеличивает количество алюминидов и уменышает их размер. В результате образуется дисперсная, размером около 5 мкм, субдендритная структура $\alpha$-твердого раствора. Когда температура расплава превышала $T_{\text {hon, }}$, в литои структуре 

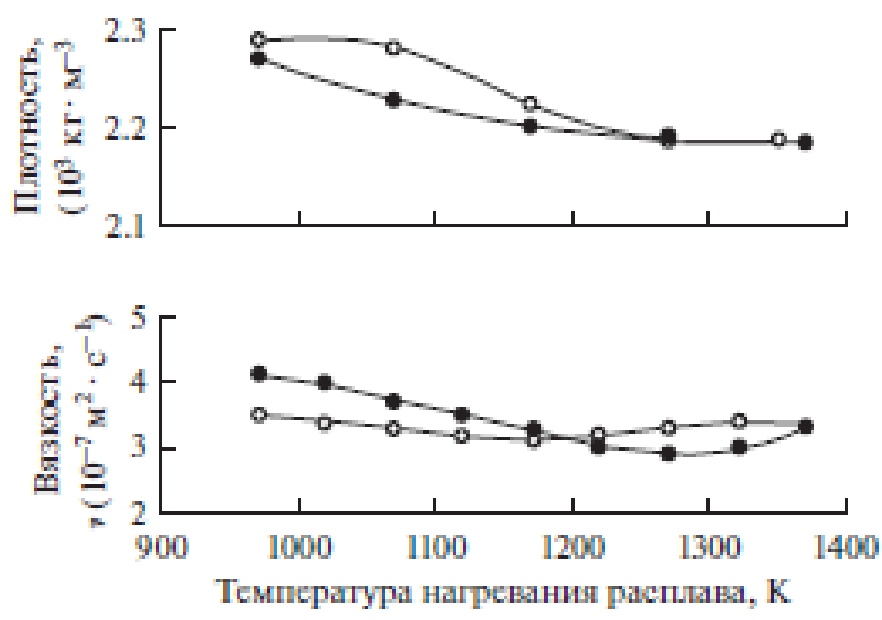

Рмс. 21. Температурнше зависимости кинематическоя нязкости у и плотности $d$ сплава Ал9 в жидком состоянии (• нагрев, о охлахдение).

сплава $\mathrm{Al}-3 \mathrm{Zr}-\mathrm{ICr}$ (мас. \%) наблюдался устоичивыи рост дисперсных метастабильных алюминидов $\mathrm{Al}_{3} \mathrm{Zr}$. C повышением температуры расплава происходит дополнительное легирование $\alpha$-твердого раствора цирконием (до $0.25-0.3 \%$ ), сопровождающееся ростом его микротвердости на $20 \mathrm{MПа}$.

Резюмируя приведенные выше экспериментальные результаты, можно сделать вывод о том, что для улучшения структуры гранулированных жаропрочных сплавов системы $\mathrm{Al}-\mathrm{Cr}-\mathrm{Zr}$ можно использовать два различных режима термическои обработки расплара.

Первыи режим с $T>T_{\text {hom }}$ позволяет подавить первичную кристаллизацию алюминидов и получить структуру аномально пересыщенного $\alpha$-твердого раствора при довольно умеренньх темпах охлаждения. Увеличение степени легирования твердого раствора повышает его термическую устоичивость и улучшает механические своиства до $\sigma_{\mathrm{n}}-380 \mathrm{MПа,} \sigma_{0.2}-340 \mathrm{MПа} \mathrm{и} \delta-12 \%$.

Второи режим, при нагревании расплава несколько ниже $T_{\text {hom, }}$, оеспечивает образование дисперсных кристаллов метастабильнои фазы $\mathrm{Al}_{3} \mathrm{Zr}$ и субдендритного $\alpha$-твердого раствора. Такая структура дополнительно упрочнена по сравнению с не перегретыми образцами, особенно в тех случаях, когда содержание циркония превышает предел его растворимости (при даннои скорости охлаждения).

Силумины, т.е. сплавы системы Al-Si используются в производстве отливок с высокими эксплуатационными своиствами, такими как герметичность, коррозионная стоикость и прочность. Типичным представителем этого класса сплавов является сплав Ал9 с почти эвтектическим составом и высокои прочностью благодаря легированию магнием. Однако использование этого сплава для производства отливок сложнои геометрическои формы требует повышения пластичности при сохранении того же уровня прочностных своиств.

Мы предложили использовать для этого термическую обработку расплава. Режимы нагрева расплава были выбраны на основе результатов измерении температурных зависимостей плотности и вязкости. Данные, приведенные на рис. 21 , подтверждают тот факт, что этот расплав представляет собои сложную микрогетерогенную систему, сохраняющую метастабильное состояние как минимум до $950^{\circ} \mathrm{C}$ [40].

Показано, что повышение температуры литья подавляет образование крупных иглообразных кристаллов кремния и сопровождается рафинированием основных струк- 
турных состапляющих: эвтектики и $\alpha$-твердого раствора. С повышением температуры первичного нагрева расплава микротвердость дендритов $\alpha$-твердого раствора в литом состоянии возрастает с 580 до $710 \mathrm{MПа} \mathrm{и} \mathrm{при} \mathrm{этом} \mathrm{возрастает} \mathrm{относительное} \mathrm{удлине-}$ ние. Максимальная прочность на растяжение $\sigma_{\mathrm{s}}$ менее чувствительна к изменениям этои температуры. Если максимальная температура нагрева расплава была ниже $T_{\text {hom, }}$ эти эффекты не сохраняются при последующем охлаждении до температуры литья $\left(720^{\circ} \mathrm{C}\right.$ в наших экспериментах). Тем не менее, величины $\delta$ вдвое превышают те же значения, полученные по стандартнои технологии, без термическои обработки исходного расплава.

Альтернативные результаты были получены после перегрева расплава выпе температуры гомогенизации. Установлено, что такая термическая обработка позволяет сохранить высокие значения $\sigma_{\mathrm{s}}$ и $\delta$ даже при низких температурах литья.

Полученные результаты доказали полезность термическои обработки расплавов как технологического средства для улучшения своиств и качества коммерческих алюминиевых сплавов.

\section{ЗАКЛЮЧЕНИЕ}

В этоһ статье мы попытались показать, что жидкие металлы являются очень сложными системами. Они могут изменять свое структурное состояние под влиянием вариации температуры или других внешних воздеиствии. С другои стороны, существует возможность сохранить характерные черты исходного расплава в закристаллизонанных образщах в результате его охлаждения с подходящеи скоростью. Это позволяет управлять структурои и своЯствами закристаллизованных сплавов путем регулирования условия плавления и затвердевания. Приведенные здесь примеры свидетельствуют о высокои эффективности термическои обработки исходных расплавов для улучшения структуры и своиств алюминиевых сплавов с различными типами диаграмм состояния.

\section{СПИСОК ЛИТЕРАТУРЫ}

1. Баум Б.А., Хасин Г.А., Тягунов Г.В. Жидкая сталь. М.: Металлургия, 1984.

2. Тлгунов Г.В., Барышев Е.Е., Цепелев В.С. и др., Металлические жидкости. Стали и сплавы, Екатеринбург: УрФу, 2016.

3. Brodova I.G., Popel P.S., Eskin G.I. Liquid metal processing: application to aluminium alloy production, London \& N.Y.: Taylor\& Francis, 2001.

4. Manov V., Popel P., Brook-Levinson E. et al. Influence of the thermal treatment of melt on the properties of amorphous materials: ribbons, bulks and glass coated microwires // Mater. Sci. Eng., 2001. A.304-306. P. 3-54.

5. Mitus A.C. Patashinsky A.Z. A statistical description of local structure of condensed matter // Physica A. 1988. 150. P. 383-391.

6. Паташинский А.3., Шумило Б.И. Теория конденсированного вещества, основанная на гипотезе локального кристаллического порядка // ЖЭТФ. 1985. 89. № 1. С. 315-328.

7. Сон Л.Д., Статистические модели структуры и переходов в жидкости, Дис. ... докт. физ.мат. Н., Екатеринбург: УрФу, 2007.

8. Mitus A.C., Patashinsky A.Z. Cluster model of melting and premelting of metals // Sov. Phys. JETP. 1981. 53. P. 798-801.

9. Mitus A.C., Patashinsky A.Z. The theory of crystal ordering // Phys. Lett. 1982. 87A. P. 179.

10. Sidorov V.E., Son L.D., Rusakov G.M., Baum B.A. The peculiarities in crystallization of iron containing 2.0 wt $\%$ of carbon // High Temp. Mater. Proc. 1995. 14. № 4. P. 263-271.

11. Русаков Г.М., Сон Л.Д., Леонтьев Л.И., Шуняев К.Ю., Структурный переход жидкостьжидкость в системе с примесью // ДАН. 2006. 411. № 4. С. 467-471.

12. Оетровский О.И., Григорян В.А., Вишкарев А.Ф., Своһ̆етва металлических расплавов, М.: Металлургия. 1988.

13. Sidorov V.E., Gushchin V.S., Baum B.A. Magnetic structure of iron containing oxygen // Phys. stat. sol. (a). 1984. 85. P. 497-501. 
14. Климснков Е.А., Гельд П.В., Баум БА., Базин ЮА. О структуре блихнето порлдка в жидких железе, кобальте и никеле // Докл. АН СССР. 1977. 230. С. 71.

15. Сон Л.Д., Сидоров В.Е. Полимеризация в стеклообразующих расплавах // Изв. Акад. наук. Сер. Физическаs. 2001. 65. № 10. С. 1402.

16. Kumar R., Sivaramakrishnan C.S. Stability of liquid Pb-Cd systems // J. Mater. Sci. 1969. 5. № 4. P. $377-382$.

17. Гаврилин И.В. Седиментационный экеперимент при изучении жидких сплавов // Изв. АН СССР. Мсталлы. 1985. № 2. С. 66-73.

18. Popel P.S., Chikova O.A., Matveev V.M. Metastable colloidal states of liquid metallic solutions // High. Temp. Mater. Proc. 1995. 4. № 4. P. 219-233.

19. Popel P.S., Sidorov V.E. Microheterogeneity of liquid metallic solutions and its influence on the structure and properties of rapidly quenched alloys // Mater. Sci. Eng.1997. A226-228. P. 237-244.

20. Гольтяков Б.П., Попель П.С., Прохоренко В.Я., Сидоров В.Е. Магнитные эффекты, свидетельствующие о метастабильной микрогетерогенности расплавов Au-Co // Paсплавы. 1988. 2. № 6. C. 83-86.

21. Попель П.С., Манов В.П., Манухин А.Б. Влияние состояния расплана на структуру пленок $\mathrm{Sn-Pb} \mathrm{после} \mathrm{затвердевания} \mathrm{//} \mathrm{Докл.} \mathrm{АН} \mathrm{СССР.} \mathrm{1985.} \mathrm{281.} \mathrm{№} \mathrm{1.} \mathrm{С.} \mathrm{107-109.}$

22. Dahlborg U., Calvo-Dahlborg M., Popel P.S., Sidorov V.E. Structure and properties of some glassforming liquid alloys // Eur. Phys. J. B. 2000. 14. P. 639-648.

23. Макесв В.В., Попель П.С. Обьсмные характеристики сплавов системы Ni-B в области от 1100 до $2170 \mathrm{~K} / /$ ЖФХ. 1990.64 . С. $568-572$.

24. Dahlborg U., Gasser J.-G., Cuello G.J., Mehraban S., Lavery N., Calvo-Dahlborg M. Temperature and time dependent structure of the molten Ni81P19 alloy by neutron diffraction // J. NonCryst Solids. 2018. 500. P. 359-365.

25. Кузин С.Н., Попель П.С. Газовые пузырьки в расплавах и их роль в формировании пористого металла // Наследетвснность в литых сплавах. Тез. Докл. 5-й научно-технической конференции. Самара: СамГТУ. 1993. С. 116-119.

26. Матвесв В.М., Попель П.С., Чикона О.А. Влияние присадок Mg, Gd, Zn, Cd, Zr, Sc, B, Ti и $\mathrm{Mn}$ на термическую устойчивость микрогетерогенного состоянил расплавов $\mathrm{Al}-5.4$ ат. \% Sn // Рacnлавы. 1995. № 2. C. 82-86.

27. Попель П.С., Никитин В.И., Бродона И.Г. и др. Влияние структурного состояния расплана на кристаллизацию силуминов// Расплавы. 1987. 1. № 3. С. 31-35.

28. Попель П.С., Коржанина О.А., Бродова И.Г. и др. Вязкость и электросопротивление расплавов $\mathrm{Al}-\mathrm{Si}$ и влилнис их структурного состолния на стросние литого металла // Расплавы. 1991. № 1. C. 10-17.

29. Константинова Н.Ю., Попель П.С., Ягодин Д.А. Кинематическая вязкость жидких сплавов медь-алюминий // ТВТ. 2009. 47. № 3. С. 354-359.

30. Kurochkin A.R., Popel P.S., Borisenko A.V., Yagodin D.A. Divergence of temperature dependenees of gamma-ray beam attenuation in the penetrated zone of $\mathrm{Cu}-\mathrm{Al}$ melts at heating and subsequent cooling // High Temperature-High Pressure. 2015. 44. № 4. P. 265-283.

31. Астафьев В.В., Курочкин А.Р., Яблонских Т.И. и др. Влияние гомогенизирующей термической обработки жидких сплавов алюминия с медью на структуру быстро закристаллизованных образцов // МиТОМ. 2017. № 8. С. 20-23.

32. Бродова И.Г., Замятин В.М., Попель П.С., Условия формиронания метастабильных фаз при кристаллизации расплавов Al-Zr // Расплавы. 1988. 2. № 6. С. 83-86.

33. Brodova I.G., Bashlykov L.V., Polents I.V., Chikova O.A. Influence of heat melt treatment on the structure and the properties of rapidly solidified aluminum alloys with transition metals // Mater. Sci. Eng. 1997. A226-228. P. 136-140.

34. Brodova I.G., Polents I.V., Bashlykov L.V. et al. The forming mechanism of ultradispersed phases in ralidly solidified aluminum alloys // Nanostructured materials. 1995. 6. № 1-4. P. 477-479.

35. Rylteev R.E., Son L.D. Statistical description of glass-forming alloys with chemical interaction: Application to Al-R systems // Physica B. 2011. N. 406. P. 3625-3630.

36. Иванов И.И., Земская В.С., Кубасов В.К. и др. Плавление, кристаллизацил и формообразование в нсвесомости. М.: Наука, 1979.

37. Добаткин В.И., Елагин В.И. Гранулируемые алюминиеные спланы. М.:Металлургия, 1981.

38. Попель П.С., Чикова О.А., Бродона И.Г., Поленц И.В. Особенности структурообразования при кристаллизации сплавов Al-In // ФММ. 1992. № 9. С.111-115.

39. Жукова Л.А., Попель С.И. Электронно-дифракционное иселедонание структуры расплавов // ЖФХ. 1982. 56. № 11. С. 2702.

40. Hohler J., Steeb J., Struktur von aluminium-indium Schmelzen mittels Rontgenweitwinkelbeugung // Z. Naturforsch. 1975. 30a. № 6-7. P. 771-774.

41. Баталин Г.И., Белобородова Е.А., Казимиров В.П. Термодинамика и стросние жидких сплавов на основе алюминия, М: Металлургия, 1983. 
THE INFLUENCE OF THERMAL TREATMENT OF INITIAL MELT ON THE STRUCTURE AND PROPERTIES OF CRYSTALLINE INGOTS OR CASTINGS

\author{
P. S. Popel ${ }^{1}$, V. E. Sidorov ${ }^{1,2}$, I. G. Brodova ${ }^{3}$, M. Calvo-Dahlborg ${ }^{4}$, U. Dahlborg ${ }^{4}$ \\ ${ }^{1}$ Ural State Pedagogical University, Yekaterinburg, Russia \\ ${ }^{2}$ Ural Federal University, Yekaterinburg, Russia \\ ${ }^{3}$ Institute of Metal Physics named after M.N. Mikhejev, Yekaterinburg, Russia \\ ${ }^{4}$ University of Rouen, Rouen, France
}

\begin{abstract}
Modern notions about the structure of liquid metals and alloys are considered. It is shown, that several types of micro-inhomogeneity and micro-heterogeneity can exist in liquid metal solutions. Their structural state can be changed as a result of composition, prehistory, temperature or pressure variations or under the influence of other external factors. These changes can be saved while subsequent cooling down to liquidus with a suitable rate and influence the structure and properties of the hardened alloy. The main attention is drawn to the influence of temperature of liquid metal heating. It is shown the possibility to develop optimal thermal smelting modes using the results of the structure and properties of melts investigation. Such optimized heat treatment of melts is an effective way to improve the quality of aluminum-based alloys.
\end{abstract}

Keywonds: micro-inhomogeneity, micro-heterogeneity, structural transformations, overheating, aluminum alloys 